\title{
The oldest North American military articles - the circumstances surrounding their enactment and their characteristics ${ }^{1}$
}

\section{INTRODUCTION}

The $16^{\text {th }}$ century and the beginning of the $17^{\text {th }}$ century are the golden age of the development of military articles in Europe. This was the time when this type of normative acts was very frequently published, modified, and it was also a time of their dynamic development. There were attempts to implement the majority of ideas in this area of military affairs by introducing them into military articles. It is worth mentioning that among the innovations, which appeared at the time, were the appearance of norms pertaining to rules of obedience which were patterned on ancient Rome, the introduction of shooting drills as well as of general military drills, and creating proper rules of behaviour in battle, enforcing hygiene rules, etc. The role of all of the aforementioned norms amounted to the following: organization of camp life (garrison); establishing the rules of military engagement; regulating the relations between soldiers and civilian population; shaping the issue of obedience, chain of command, and regulating the significance of an order; the introduction

${ }^{1}$ K. Łopatecki, Najstarsze pótnocnoamerykańskie artykuły wojskowe, "Czasopismo PrawnoHistoryczne" [Journal of Law and History] [CPH] 2013, t. LXV, issue 1, pp. 175-201. The current version of the article has been prepared as a part of the SONATA research project of Narodowe Centrum Nauki [the National Science Centre]. The project number is 2016/23/D/HS3/03210 and it is entitled "The military revolution as a modernization factor in the public finance and state organization of the Polish-Lithuanian state in the comparative perspective." 
of military crimes and determining potential maximum sanctions stipulated for committing them. ${ }^{2}$

Geoffrey Parker, while analyzing the phenomenon of "the military revolution" at the turn of the seventeenth century, pointed out the ease with which new solutions were disseminated in the military. ${ }^{3}$ New inventions, concepts, as well as tactical and strategic solutions did not constitute closely guarded military secrets. The flow of information occurred together with recruitment of foreign military engineers, officers, and even of entire military units. Military treatises published in print were widely available. ${ }^{4}$ The most effective method of disseminating "volley fire" - this issue which constituted the basis for Parker's work - was in the form of drawings depicting soldiers in the course of military drills. These drawings were later published in the form of engravings. ${ }^{5}$ This phenomenon can be transposed to a wider background, namely the dynamic development of acts known as "military articles."

The characteristic feature of the development of the early modern military articles, which originated in Holland, Sweden, Spain, England, and France, was their dissemination outside of European borders. ${ }^{6}$ Military models were transposed from metropolises to factories and colonies located in North and South America, Africa as well as in Asia. People emigrating from Europe to distant lands carried with them military knowledge which was then adapted to new circumstances. ${ }^{7}$ Furthermore, the civilizations outside of Europe which undertook military reforms

${ }^{2}$ K. Łopatecki, 'Disciplina militaris'w wojskach Rzeczypospolitej do połowy XVII wieku [Disciplina militaris in the armies of the Polish-Lithuanian Commonwealth until the middle of the $17^{\text {th }}$ century], Bialystok 2012, pp. 701-702.

${ }^{3}$ G. Parker, From the House of Orange to the House of Bush: 400 years of military revolutions, or how to prepare for the next Gulf War, "Military Spectator" 2003, vol. 172, issue 4, pp. 187-190. Compare S.J. Walker, Arms and the Man: Constructing the Soldier in Jacques de Gheyn's "Wapenhandelinghe," "Nederlands Kunsthistorisch Jaarboek" 2007-2008, no. 58, pp. 138-161.

${ }^{4}$ It was popular to create military treatises in handwritten form in the $16^{\text {th }}$ century. There were more works of this kind than printed ones. However, it was not done in order to keep the knowledge secret as copies were not rare. The most important thing was to increase the prestige of a treatise in order to make it a unique work. M. Rogg, Die Kriegsordnung Albrechts des Älteren von Brandenburg, Herzog in Preussen [in:] H.J. Bömelburg, B. Chiari, M. Thomae (eds.), Die Kriegsordnung des Markgrafen zu Brandenburg Ansbach und Herzogs zu Preussen Albrecht des Älteren - Königsberg 1555, Braunschweig 2006, pp. 23-24.

5 J. de Gheyn, The renaissance drill book, ed. D.J. Blackmore, London 2003.

${ }^{6}$ Compare J. Black, European Overseas Expansion and the Military Revolution [in:] G. Raudzens (ed.), Technology, disease, and colonial conquests, sixteenth to eighteenth centuries, Leiden 2001, pp. 1-30.

${ }^{7}$ K. Roy, The hybrid military establishment of the East India Company in South Asia: 1750 1849, "Journal of Global History” 2011, no. 6, pp. 195-218. 
according to the European model were forced to issue legal regulations which were similar to military articles. ${ }^{8}$

A phenomenon of the development of military law was editing and, subsequently, enacting military articles by colonial legislative bodies. These regulations were intended for the militia which was being formed in the colonized areas and composed of the citizens of these lands. The following article presents this phenomenon as it occurred in English lands in North America in the $17^{\text {th }}$ century. Studying their contents as well as the circumstances of their creation will enable the portrayal of the $1^{\text {st }}$ stage of the development of the militia, its discipline levels, and, most importantly, it will make possible the establishing of the source of reception and the adoption level of models from the metropolis. ${ }^{9}$

The article is written in the "military revolution" paradigm. However, in the context of the militia and of the legal rules which were in effect in those formations, it is very close to another paradigm, namely "social disciplining" (the so-called Sozialdisziplinierung). ${ }^{10}$ Even though the term itself is connected with research into absolute monarchy, ${ }^{11}$ it can also be successfully used in parliamentary monarchies. The beginnings of the policy of instilling schematic and automatic obedience in the population (self obedience), limiting spontaneity and standardization of social attitudes can already be connected with European cities in the $15^{\text {th }}$ century. Numerous legal acts were promulgated at the time which attempted to regulate almost every sphere of life (clothing, behaviour, prices, and sanitary issues). States in which bureaucracy and military units were taking shape started to impose discipline in the

${ }^{8}$ It is worth mentioning that in Japan, where the rules of military discipline created in ancient Rome were completely unknown, there was also an attempt to codify the rules of conduct in characteristic military articles. In particular, the work of Tokugawa Ieyasu should be accentuated. He proclaimed military laws in a military camp near the Odawara castle in 1590 . They were similar in form to the German Artikelbrief from the end of the $15^{\text {th }}$ century. The act was composed of 14 regulations which encompassed norms which were very similar to the European solutions such as the protection of traders, the civilian population, and it also contained mentions of the crimes of desertion, disobedience, etc. The articles were discussed and translated by A.L. Sadler, The Maker of Modern Japan, London 1937, p. 161. See: M. Stavros, Military Revolution in Early Modern Japan, "Japanese Studies" 2013, vol. 33, no 3, pp. 243-261.

9 The phenomenon of transposing legal institutions and regulations from the metropolis to the colonies was highlighted by: D. Nagl, No Part of the Mother Country, but Distinct Dominions Rechtstransfer, Staatsbildung und Governance in England, Massachusetts und South Carolina, 1630 1769, Berlin 2013. The transfer of English solutions to the colonies was not an automatic process as the local factors played a huge part in it.

${ }^{10}$ T. Schwager, Militärtheorie im Späthumanismus: Kulturtransfer taktischer und strategischer Theorien in den Niederlanden und Frankreich (1590-1660), Berlin 2012, p. 4 et seq.

${ }^{11}$ G. Oestreich, Strukturprobleme des europäischen Absolutismus [in:] idem, Geist und Gestalt des frühmodernen Staates, Berlin 1969, pp. 179-197. 
$16^{\text {th }}$ century (Socialregulierung). ${ }^{12}$ In the next stage, a disciplined society accepts changes leading to the creation of an absolute monarchy with fewer reservations. This does not mean that this phenomenon cannot be used for research into parliamentary monarchy. This issue is even more interesting when one takes into account that instilling virtues of diligence, obedience, order, and punctuality also serves the growing bourgeoisie. Moreover, it constitutes the foundations for the development of modern capitalist phenomena and the modernization of states. In consequence, it can lead to the process of democratization (Fundamentaldemokratisierung). ${ }^{13}$

\section{MILITARY ARTICLES AS AN INSTRUMENT OF COLONIAL POLICY}

While starting the colonization process of newly discovered lands, European states announced military articles for both seamen and soldiers already at the beginning of a sea voyage. However, it was not an infrequent occurrence that legal regulations needed to be adjusted to new political and military circumstances which in turn forced leaders to issue new legal regulations. The oldest example were Ordenanzas Militares which were created by Hernán Cortés on the $22^{\text {nd }}$ of December 1520 in Tlaxcala. ${ }^{14}$ The Spanish leader extensively explained the necessity of independently proclaiming the act in its preamble. He drew attention to the significantly insufficient forces and the distance from the metropolis which made acquiring assistance impossible. These issues significantly influenced the type of employed sanctions. First and foremost, the punishment in the form of mutilation was abandoned and the option of sentencing soldiers to the death penalty was drastically limited. Capital punishment was only stipulated in the case of mutiny, disobedience, and appropriating spoils of war (which should have been amassed and divided together). The dominant system of punishment was one of composition,

${ }^{12}$ D. Tilgner, Sozialdisziplinierung und Sozialregulierung: die Policeyordnungen für Schleswig-Holstein von 1636 und für das Amt Bergedorf von 1623, Münster 2000, passim, especially pp. 29-54, 175 (Table 4).

${ }^{13}$ G. Oestreich, Strukturprobleme..., p. 195; L. Bauer, M. Herbert, Geburt der Neu zeit. Vom Feudalsystem zur Marktgesellschaft, Munich 1988, p. 315; S. Ogilvie, 'So that Every Subject Knows How to Behave': Social Disciplining in Early Modern Bohemia, "Comparative Studies in Society and History" 2006, vol. 48, no. 1, pp. 38-78. Compare: W. Freitag, Mißverständnis eines 'Konzeptes'. Zu Gerhard Oestreichs, Fundamentalprozeß'der Sozialdisziplinierung, “Zeitschrift für Historische Forschung" 2001, vol. 28, no. 4, pp. 513-538.

${ }^{14}$ Ordenanzas Militares [in:] W.H. Prescotts, History of the conquest of Mexico, vol. II, London 1854, pp. 388-392. On the organization of the Spanish army in the $16^{\text {th }}$ century America: L. Weckmann, The medieval heritage of Mexico, vol. 1, New York 1992, pp. 87-103. 
or sanctions in other words, which did not jeopardize the army's troop strength. Corporal punishments were employed only in special circumstances.

The English colonial policy in the $17^{\text {th }}$ century was mainly concentrated on the area of North America. The first settlers who crossed the Atlantic Ocean and arrived in the new lands had to organize themselves in a military fashion for two reasons. The first one was their small strength, while the second, and the more important reason, was the hostile attitude on the part of the natives. ${ }^{15}$ For this reason, normative acts were passed, similarly to military articles, which included in their subjective scope all inhabitants. ${ }^{16}$ It was also a very important factor which led to imposing the rules of social discipline. Moreover, it got people accustomed to the introduction of regulations pertaining to militia units in the future.

In case of danger, English authorities sent an army which was issued disciplinary regulations at the beginning of its sea voyage or the commanders in chief - governors - of the army were authorized to publish them. ${ }^{17}$ For instance, the Crown sent out a contingent of 1000 soldiers under the command of Colonel Herbert Jeffrey in order to suppress Bacon's rebellion. ${ }^{18}$ Special regulations were prepared for the expeditionary force and the commander in chief was informed of them by Henry Coventry, the Secretary of State for the Southern Department, on the $19^{\text {th }}$ of October 1676. Charles II of England handed over "the printed book of articles of war now in Jeffrey's hands published in 1673 and signed by his Majesty is the form of articles he is to follow during the war in Virginia." ${ }^{19}$ An alternative solution was employed on the territories of Jamaica, which was captured by the English in 1655.

15 A.J. Hirsch, The Collision of Military Cultures in Seventeenth-Century New England, "The Journal of American History” 1988, vol. 74, no. 4, pp. 1187-1212.

${ }^{16}$ An example of such actions were "Articles, Lawes, and Orders, Divine, Politique, and Martiall for the Colony in Virginea" as well as "The Summarie of the Marshall Lawes" which were supplemented by a number of detailed instructions and sets of rules and regulations for soldiers and officers. They were originally proclaimed in 1610 and they were later modified several times in 1611. For The Colony in Virginea Britannia. Lawes Divine, Morall and Martiall, London 1612, pp. 9-68. The first settlers of the Plymouth colony also thought about creating a special normative act to combine civilian laws with military ones in 1621. See: A. Young (ed.), Chronicles of the Pilgrim fathers of the Colony of Plymouth: from 1602-1625, Boston 1844, pp. 196-197.

${ }_{17}$ W.N. Sainsbury (ed.), Calendar of State Papers, Colonial Series, America and West Indies, vol. 7: 1669-1674, London 1889, p. 351.

18 W.M. Billings, Sir William Berkeley and the forging of colonial Virginia, Baton Rouge 2004, p. 249 et seq.

19 W.N. Sainsbury (ed.), Calendar of State Papers, Colonial Series, America and West Indies, vol. 9: 1675-1676, London 1893 [reprint: Vaduz 1964], p. 495. The only military articles printed in England in 1673 were Articles and Rules for the Better Government of his Majesties Forces by Land During this Present War, commonly called The Prince Rupert Articles. They were published on the $6^{\text {th }}$ of December 1672 for the purposes of the war with Holland; however, they were first printed one year later. A critical edition: G.B. Davis, A Treatise on the Military Law of the United States, Clark 2007, pp. 567-580. 
A significant military force was stationed on the island and, as a result, numerous military articles were issued by its governors. ${ }^{20}$

All of the regulations mentioned above were in essence articles for English mercenary armies, which were recruited in the metropolis. ${ }^{21}$ Due to huge distances, fielding voluntary units was frequently the only means of resisting the enemy. They held the enemy at bay until the regular army arrived. In consequence, it created a need to form militia units which were composed of people of European origin who inhabited the lands which were being colonized. ${ }^{22}$ However, forming such units created problems pertaining to applying military law. Volunteers did not formally constitute a part of the King's army and that is why local bodies with legislative authority started to issue special military articles for them..$^{23}$

Spain was the first country which had experiences concerning the issuing of special regulations for the needs of the militia created outside of continental Europe. The situation pertained to the Canary Islands which were in danger of an invasion by the English as well as by Muslim rulers. As a consequence, Phillip II of Spain decided to carry out a centralization process connected with the strengthening of the islands' military power. He wanted to create a permanent military formation composed of the islands' inhabitants and, to this end, Jerónimo de Saavedra was sent there in 1587. It was his duty to give military training to the locals. Three years later, don Luis de la Cueva y Benavides became the governor and captain

${ }^{20}$ For instance: Governor Thomas Modyford proclaimed on the $1^{\text {st }}$ of January 1667 "Articles and military laws [...] for the better ordering and governing his Majesty's forces belonging to Jamaica." W.N. Sainsbury (ed.), Calendar of State Papers, Colonial Series, America and West Indies, vol. 5: 1661-1668, London 1880, p. 437. See also: J.W. Fortescue (ed.), Calendar of State Papers, Colonial Series, America and West Indies, vol. 12: 1685-1688, London 1899, pp. 71-72; J.W. Fortescue (ed.), Calendar of State Papers, Colonial Series, America and West Indies, vol. 15: 1696-1697, London 1904, p. 38, 160.

${ }^{21}$ More on the justice system: S.R. Frey, The British Soldier in America: A Social History of Military Life in the Revolutionary Period, Austin 1981, pp. 71-93.

${ }^{22}$ Militia and levy en masse were also gladly employed in Europe. They were especially necessary on the borders which were in constant danger of raids. A whole system of border protection was implemented there. One can provide the following as examples: the French defense system created in the $2^{\text {nd }}$ half of the $17^{\text {th }}$ century and located on the lands on the border with the Dutch Republic; another example were the solutions introduced on the eastern rims of the Grand Duchy of Lithuania which were endangered by Russian expansion. G. Satterfield, Princes, Posts and Partisans: The Army of Louis XIV and Partisan Warfare in the Netherlands (1673-1678), Leiden-Boston 2003, pp. 56-58, 140-143, 159-162, 237-250, 267; K. Łopatecki, Organizacja, prawo i dyscyplina w polskim i litewskim pospolitym ruszeniu (do połowy XVII wieku) [The organization, law and discipline of the Polish and Lithuanian levy en masse (until the middle of the $17^{\text {th }}$ century)], Białystok 2013, pp. 412-432.

${ }^{23}$ English models were naturally employed in North America. See: L. Boynton, The Elizabethan militia, 1558-1638, London-Toronto 1967, pp. 252-307; K. Sharpe, The personal rule of Charles I, New Haven-London 1992, pp. 487-506, 792-812; K.F. Zelner, A Rabble in Arms: Massachusetts Towns and Militiamen during King Philips' War, New York-London 2009, pp. 19-28. 
general of the Islands. He was authorized - after receiving prior consent of the local authorities - to summon the militia for which military articles were enacted on the $13^{\text {th }}$ of July 1590 in the town of San Cristóbal de La Laguna. ${ }^{24}$

Similar actions had to be undertaken by the communities inhabiting the east coast of North America in the $60 \mathrm{~s}$ and 70 of the $17^{\text {th }}$ century. ${ }^{25}$ The act passed by the General Assembly in the Maryland colony, chaired by Governor Phillip Calvert, in 1661 needs to be counted among the oldest documents regulating militia discipline. ${ }^{26}$ Analogous actions were undertaken on the islands in the Caribbean. John Vaughan, the Governor of Jamaica, issued special military articles in 1676 for the inhabitants and the units stationed there due to the danger of a slave revolt. The proclamation was connected with the articles being passed by the Council of Jamaica on the $17^{\text {th }}$ of February. Afterwards, copies were made and they were subsequently handed over to the colonels. ${ }^{27}$ Military leaders were obliged to abide by military laws, organize regimental court martials, recruit volunteers for the army as well as to prepare a list of all white inhabitants of the plantations. ${ }^{28}$ Shortly after, on the $18^{\text {th }}$ of May 1676, William Stapleton, the Governor of Antigua, also introduced military articles which were "customary on other islands." This can suggest that the articles may have been modelled on the laws issued by John Vaughan. ${ }^{29}$

${ }^{24}$ J. Peraza de Ayala, Las ordenanzas militares para Canarias en 1590, "Revista de Historia Canaria" 1968, no. 41, pp. 1-4; a critical edition of this act which was comprised of 25 articles: ibidem, pp. 6-10.

${ }^{25}$ Similar regulations were issued on the islands in the Caribbean Sea. For instance, the following regulation was issued in Antigua on the $27^{\text {th }}$ of March 1691: An Act for regulating the Militia and Forces of these Islands and establishing divers Rules and Articles of War. See: A. Brown (ed.), The Laws of the Island of Antigua: Consisting of the Acts of the Leeward Islands, vol. I, London 1805, p. 2. Similar regulations were issued, inter alia, in 1702, 1788, and 1790 (ibidem, pp. 165-168, 553, 572).

${ }^{26}$ Unfortunately, its contents remain unknown. W.N. Sainsbury (ed.), Calendar of State Papers..., vol. 5, p. 24 .

27 Their contents are unknown. The only thing which is known for certain is that they were comprised of six chapters: "Duties to his Majesty's authority and government"; "Duties towards superior officers"; "Duties in marching and in action"; "Duties in camp and in garrison"; "Rules for regulation of musters"; "Administration of justice." These names suggest that this act was created on the basis of military articles which were divided into chapters. Such acts were: Lawes and Ordinances of Warre Established for the better Conduct of the Army by His Excellency the Earle of Essex, London 1642; Lawes and Ordinances of Warre Established for the better Conduct of the Army by His Excellency The Earle of Waewick, London 1642; Articles and Rules for the Better Government (1673) [in:] G.B. Davis, A Treatise on the Military Law..., articles 1-6, pp. 567-580. The most similar chapters are presented in the last act. Consequently, it is probable that the articles refer to the regulations of 1673 .

${ }^{28}$ W.N. Sainsbury (ed.), Calendar of State Papers..., vol. 9, pp. 352-353; J.M. Collins, Martial Law and English Laws, c.1500 - c.1700, Cambridge 2016, pp. 227-230.

29 The Laws of the Island of Antigua..., p. 67; W.N. Sainsbury (ed.), Calendar of State Papers..., vol. 9, pp. 395-396. 
The time between 1675 and 1676 was a watershed period in North America. This was the time when a war broke out on the territories of Massachusetts, Connecticut, Rhode Island, and Maine between the colonists (supported by the Mohegan and Pequot tribes) and American Indians led by Metacomet, the chief of the Wampanoag tribe. ${ }^{30}$ Besides this conflict, which was also known as "King Philip's war," the colonists inhabiting Virginia also had to face the natives in $1676 .{ }^{31}$ The colonists had to bear the brunt of this conflict as well and that is why it was necessary to create military articles written by local legislative bodies for the needs of the local militia.

\section{MILITIA ARTICLES OF THE COLONY OF VIRGINIA OF 1676}

Regulations proclaimed in Virginia are one of the oldest acts pertaining to militia discipline which can also be equated to "military articles" issued for the needs of professional mercenary units. The first parliamentary body (the General Assembly) in the Western Hemisphere started functioning in this colony in Jamestown in 1619. This institution was reorganized by William Berkeley in 1643. He, among other things, made the General Assembly a bicamercal institution by introducing the House of Burgesses one year after he had been nominated for the position of governor. This parliament did not have a set term of office. Instead, it was working continuously between 1661 and 1676 over the course of 17 sessions. Robert Wynne was the Speaker of the Virginia House of Burgesses between 1662 and 1674 and Augustin Warner took over the position after this period. ${ }^{32}$

The conflict between the natives and the colonists was growing violently in 1674. First regular skirmishes took place in September of the following year. In the face of military danger, William Berkeley decided to call another session of the General Assembly. ${ }^{33}$ There was a session in progress between the $21^{\text {st }}$ of September 1674 and the $7^{\text {th }}$ of March 1676 in Jamestown, which was chaired by Warner. ${ }^{34}$ The output of this session was the enactment of regulations which prepared the colony

${ }^{30}$ J.D. Drake, King Philip's War: civil war in New England, 1675-1676, Amherst 1999; E.B. Schultz, M. Tougias, King Philip's War: the history and legacy of America's forgotten conflict, Woodstock 2000.

${ }^{31}$ H.C. Rountree, Pocahontas's people: the Powhatan Indians of Virginia through four centuries, Norman 1990, p. 96 et seq.

${ }_{32}$ J. Kukla, Speakers and Clerks of the Virginia House of Burgesses, 1643-1776, Richmond 1981, pp. 10-12, 63-67.

${ }^{33}$ R.M. Utley, W.E. Washburn, Indian Wars, New York 2002, pp. 24-31.

34 W.W. Hening (ed.), The Statutes at Large; being a Collection of all the Laws of Virginia, vol. II, New York 1823, p. 326; W.N. Sainsbury (ed.), Calendar of State Papers..., vol. 9; also W.N. Sainsbury (ed.), Addenda 1574-1674, London 1893, p. 357. 
for war. ${ }^{35}$ For this reason, "An act for the safeguard and defence of the country against the Indians" was issued. This document was signed by the Governor, William Berkeley, and the Speaker, Augustin Warner. The document was comprised of two parts. The first one proclaimed the laws pertaining to mobilization and the method of waging war, while the second approved the military articles for the militia. ${ }^{36}$ Its issuing was a direct result of the enactment of The Militia Act in 1673, which ordered the militia in both organizational and legal terms. ${ }^{37}$

The first part was introduced by a preamble which provided the grounds necessitating the introduction of military reforms. Indians, according to the members of parliament, were committing continuous assaults on the colonists and that was why the Colony of Virginia declared war on all the natives who committed acts of aggression. Militia units were formed for this reason and it was indicated where the soldiers were to be stationed, which county they were to come from, and who was to be their commanding officer. It was also decided where depots were going to be located; it was assigned which soldiers were going to be responsible for procurement; and the issuing of guns and ammunition to each fort was approved.

Provisions for soldiers were determined in detail. Military pay was distinctive in comparison to its European counterparts as bullion was not in use. Instead, the most commonly used "currency" of the period was employed, namely tobacco. ${ }^{38}$ The pay for horsemen was four time higher due to the need to buy a horse by oneself as well as to field another in case the first one was lost. Commanding officers were obliged to have a surgeon on each fort's staff as well as to make a list of all the citizens serving in the militia. Moreover, there were attempts to take advantage

${ }^{35}$ The parliamentary acts of 1679 refer to military articles which were enacted three years earlier. W.W. Hening (ed.), The Statutes at Large..., vol. II, p. 440; compare with Annual Report of the West Virginia Bar Associations, Charleston 1919, p. 107.

${ }^{36}$ An act for the safeguard and defence of the country against the Indians [in:] W.W. Hening (ed.), The Statutes at Large..., vol. II, pp. 326-336. The aforementioned regulations also contain a mention of Nathaniel Bacon (in the rank of colonel) who, together with Major John Page, was authorized to carry out recruitment in the county of York. However, he should not be identified as Nathaniel Bacon who was the leader in the rebellion, who was frequently referred to as "Junior." L. Middleton, Revolt, U.S.A., New York 1977, pp. 22-25.

${ }^{37}$ P.A. Bruce, Institutional History of Virginia in the Seventeenth Century: an inquiry into the religious, moral, educational, legal, military, and political condition of the people, vol. 2, New York-London 1910, pp. 37-39. A similar situation took place in Jamaica where The Militia Act, supplemented by military articles, was enacted in 1671 due to the danger of a Spanish attack. W.N. Salisbury (ed.), Calendar of State Papers, Colonial Series, America and West Indies, vol. 7: 16691674, p. 272.

${ }^{38}$ An infantry soldier received 500 pounds of tobacco each year, while a cavalry soldier received 2000 pounds per year. Officers received their pay monthly: 600 pounds of tobacco for a captain and 400 pounds for a lieutenant. It was a widely accepted payment method in Virginia at the time. See: W.M. Billings, Sir William Berkeley and the Forging of Colonial Virginia, Louisiana 2010, pp. 148, 226-227. 
of the tribal divisions among Indians and institutionalize them. Military personnel were obliged to reward the natives who brought an enemy alive or brought proof of an enemy's death ${ }^{39}$. After the General Assembly session ended, broad discretionary powers were granted to the governor and to the war council. They had the right to issue new laws or to amend old laws as well as to disband the army after victory had been achieved.

The second part of the act stated military laws concerning the militia: "The Articles, rules and orders to be observed and kept by the army as well in the several garrisons as in the field, are as followeth." ${ }^{40}$ The General Assembly only approved them as the wording was in the purview of the Governor and - most probably - of the officers selected by him. The contents of these laws were quoted by the General Assembly and, in the first part, additionally gave them importance equal to the regulations binding soldiers in garrisons, camps and during draft. Captains and their subordinate officers were obliged to punish criminals according to the aforementioned regulations. The most serious felonies which could have been punished by death were supposed to be adjudicated by the war council. ${ }^{41}$ The division into higher and lower military courts, whose jurisdiction depended on the seriousness of a crime and the type of sanction, was commonly employed in Europe. ${ }^{42} \mathrm{How}$ ever, the solutions enacted in Virginia did not contain any information pertaining to appeals, which were commonly used on the Old Continent in the second half of the $17^{\text {th }}$ century.

The normative act was relatively short and it consisted of 26 regulations. ${ }^{43} \mathrm{As}$ a rule, English military articles for mercenary armies were 2.5 to 3 times longer and even the legal regulations themselves were more elaborate. ${ }^{44}$ A detailed analysis

39 Three matchcoats were paid for a prisoner, while one matchcoat was paid for the head of a dead enemy. This double rate indicates that the authorities were more interested in capturing prisoners than simply killing the natives. However, the latter form became dominant later. B. Madley, Reexamining the American Genocide Debate: Meaning, Historiography, and New Methods, "The American Historical Review" 2015, vol. 120, no. 1, p. 115.

${ }^{40}$ A characteristic of the proclaimed laws: R. Hildreth, The History of the United States of America: Colonial, 1497-1688, vol. 1, New York 1863, pp. 530-532.

${ }^{41}$ W.W. Hening (ed.), The Statutes at Large..., vol. II, pp. 332-333: "Be it enacted by the authority aforesaid, that certaine articles rules and orders (being in number twenty six) to be observed and kept by the army as well in garrison as in field, and are hereunto annexed be put in execution; and that any captaine of a fort or other subordinate officer comanding a party be impowred to punish any the offences therein mentioned upon any of his or their company offending not extending to life or member, bat that capital and greate crimes be adjudged at a councell of warr."

${ }^{42}$ S.R. Frey, The British Soldier in America..., p. 81.

${ }^{43}$ The Articles, rules and orders to be observed and kept by the army as well in the several garrisons as in the field, are as followeth [in:] W.W. Hening (ed.), The Statutes at Large..., vol. II, pp. 333-336. A short characteristic: P.A. Bruce, Institutional History of Virginia..., pp. 69-70.

${ }^{44}$ There were 64 articles by James II which were published in 1685 and there were 74 articles by Prince Rupert which were published in 1673. 
of the contents shows that they constituted a compilation of the Swedish military articles enacted in $1621 .{ }^{45}$ However, it was not a direct reception because they were translated into English and published in print twice - in 1632 and 1639. ${ }^{46}$ 25 regulations are a faithful recreation of Gustav II Adolf's articles, complete with the grammatical and stylistic idiosyncrasies. The American norms are shorter as a rule and the sanctions were sometimes made lighter in comparison with their Swedish counterparts. ${ }^{47}$ Certain regulations are completely the same (e.g. articles 9-23, 10-24, 13-38, 17-47, 18-51,20-53, 23-60), while others only differ in single words or phrases. ${ }^{48}$ Furthermore, the whole layout of the regulations is adapted to reflect the Swedish model, while the legal writing units preserve the original layout. A detailed collation is presented in Table 1. The first column contains the contents of the English laws. The second column presents the counterparts of the Swedish military articles translated into English in 1632 and 1639. Corresponding fragments in both versions are underlined. ${ }^{49}$

The collation above unequivocally shows that the person/people responsible for the preparation of the military articles had to possess a printed copy of the translated Gustav II Adolf laws. The question concerning the influence connected with the presence of the Swedish armies in North America remains open. The Swedes

${ }^{45}$ O. Brusiin, Gustav II Adolfs krigsartiklar. Några synpunkter, "Tidskrift utgiven av Juridiska Föreningen i Finland" 1943, no. 5-6, pp. 373-393.

${ }^{46}$ The Svvedish discipline, religious, civile, and military, London 1632, pp. 39-69; R. Ward, Animadversions of Warre, London 1639, pp. 41-54; Articles of Warr instituted by the Kinges Majesty of Sweden, London b.d.w., pp. 1-23. W. Winthrop (Military Law and Precedents, Washington 1920 , p. 19) indicates only one version (the one from 1639) of the translations of the Gustav Adolf military articles. On the basis of the analysis of the regulations, it seems that the articles in Virginia were developed on the basis of the printed version of 1632 .

${ }^{47}$ For instance, article 6: "That all officers and souldiers be obedient to the commander in cheife and the officers next under him, in whatsoever they shall command for the service of the king." A corresponding regulation from the Swedish version of the articles of 1632 states: "Next, shall our Officers and soldiers be obedient unto our Generall and Feild-Marschal, with other our Officers next under them, in whatsoever they shall command, belonging unto our service: upon paine of punishment as followeth."

${ }^{48}$ For example, article 14 of laws of 1676 stated: "That no man shall hinder the marshall or other officer in executing his office in punishing offenders upon paine of death." The regulation in Swedish laws: "No man shall hinder the Provost Marshall Generall, his Lieftenant or servants, when they are to execute anything that is for our service; who does the contrary, shall lose his life." Analogically, article 18 states: "No man shall presume to make an allarme in the campe or quarters, or shoote of his muskett in the night time upon pain of death." Its counterpart (article 51) in the Swedish regulation is: "No man shall presume to make any Alarme in the Quarter, or to shoot off his Musket in the night time, upon paine of Death." See: The Articles, rules and orders..., article 14, p. 335; Code of articles of king Gustavus Adolphus of Sweden (1621) [in:] W. Winthrop, Military Law..., article 36, p. 909.

49 The Articles, rules and orders..., pp. 333-336; The Svvedish discipline..., pp. 39-69; R. Ward, Animadversions of Warre, pp. 41-54. 


\begin{tabular}{|c|c|c|c|c|c|c|c|c|c|c|c|}
\hline 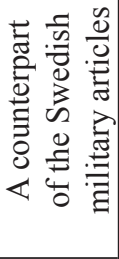 & $\begin{array}{l}\text { d } \\
\text { N } \\
\text { 这 }\end{array}$ & (7) & 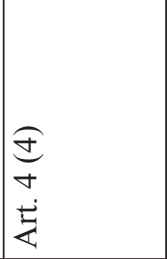 & $\begin{array}{l}\sqrt{n} \\
\text { in } \\
2 \\
\end{array}$ & & $\begin{array}{l}2 \\
\dot{3} \\
\end{array}$ & 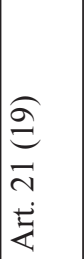 & $\begin{array}{l}\text { ㄱ } \\
\text { 运 }\end{array}$ & 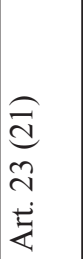 & 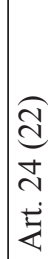 & 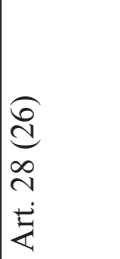 \\
\hline 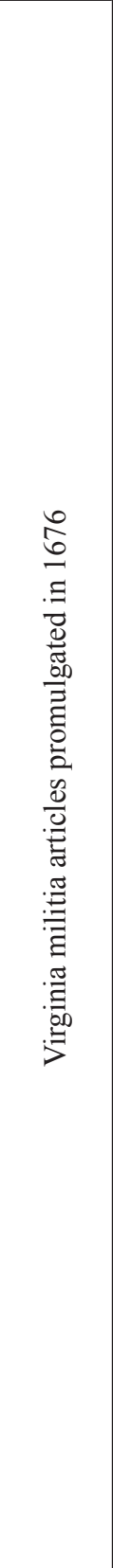 & 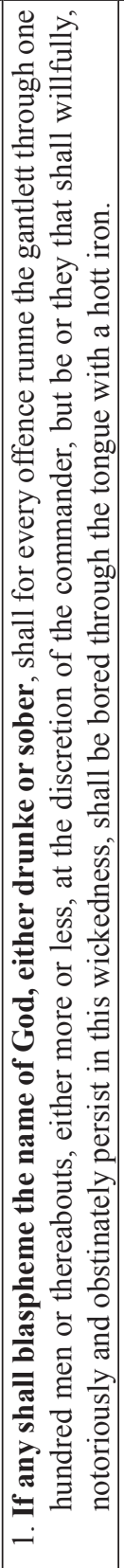 & 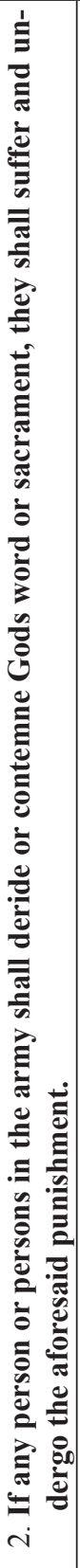 & 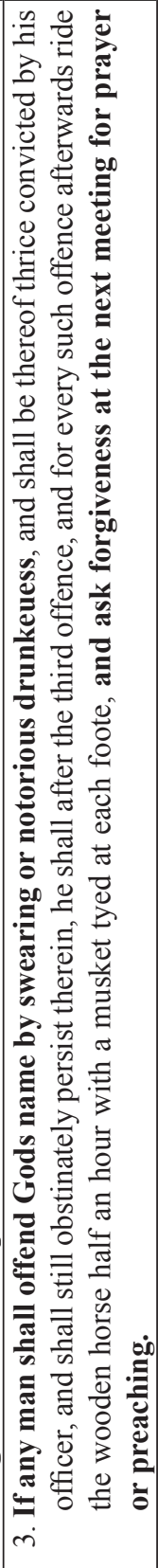 & 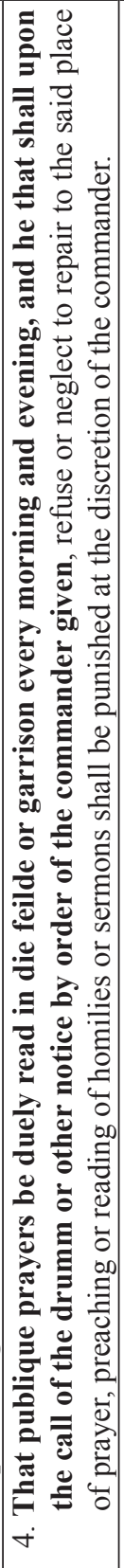 & 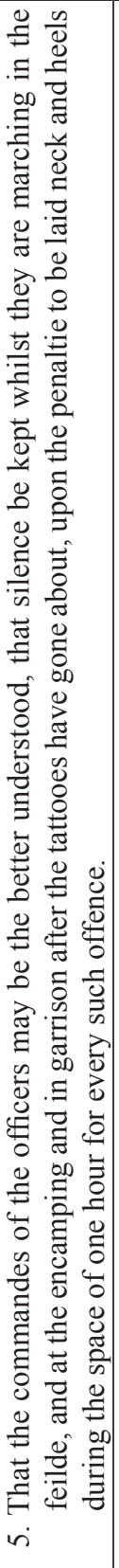 & 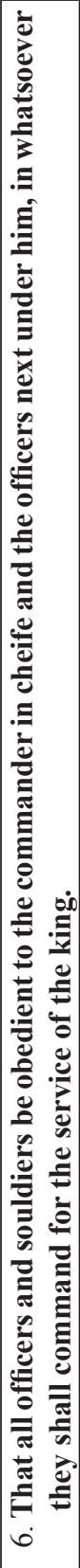 & 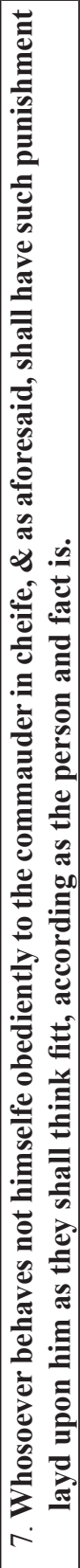 & 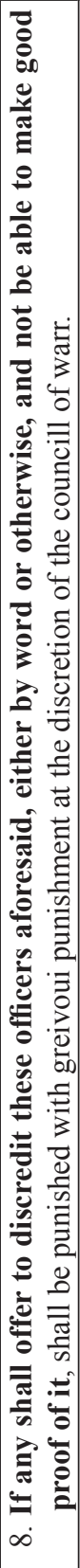 & 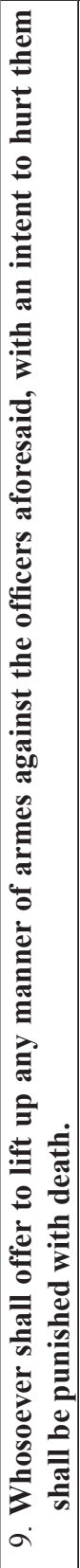 & 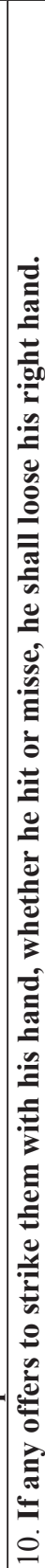 & 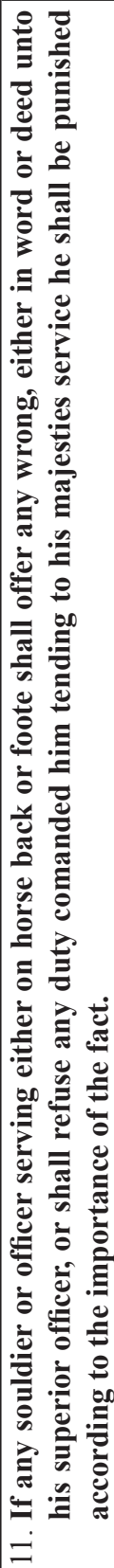 \\
\hline
\end{tabular}




\begin{tabular}{|c|c|c|c|c|c|c|c|c|c|c|c|c|}
\hline 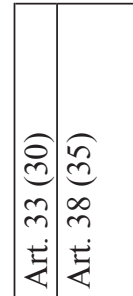 & $\mid \begin{array}{l}0 \\
0 \\
0 \\
\text { m. } \\
\vdots \\
\dot{3}\end{array}$ & 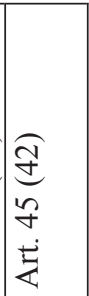 & 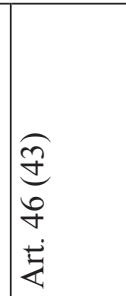 & $\begin{array}{l}\text { 过 } \\
\text { 字 } \\
\dot{3}\end{array}$ & $\begin{array}{l}\stackrel{\infty}{+} \\
\stackrel{\infty}{n} \\
\text { 这 }\end{array}$ & 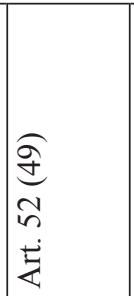 & 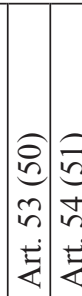 & 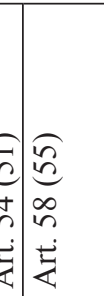 & $\begin{array}{l}0 \\
0 \\
0 \\
8 \\
8 \\
\dot{3}\end{array}$ & 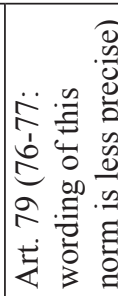 & $\left\{\begin{array}{l}\infty \\
\stackrel{\infty}{\Xi} \\
\infty \\
\dot{\vec{z}}\end{array}\right.$ & 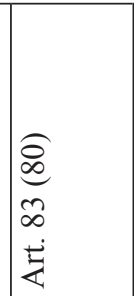 \\
\hline 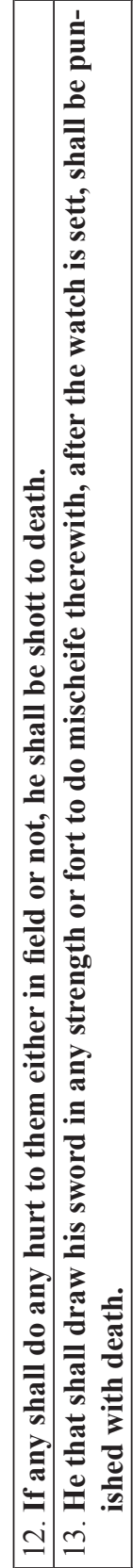 & 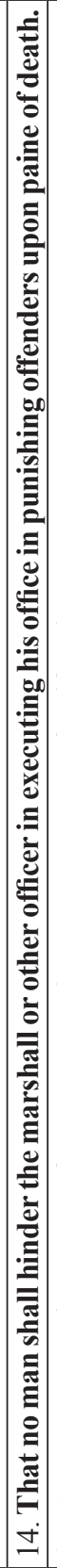 & 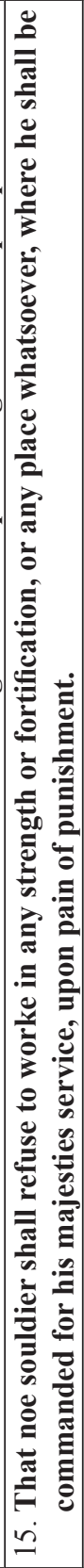 & 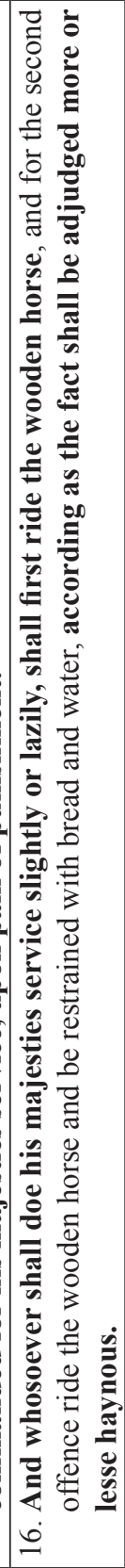 & 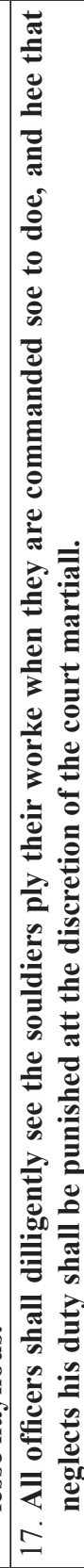 & 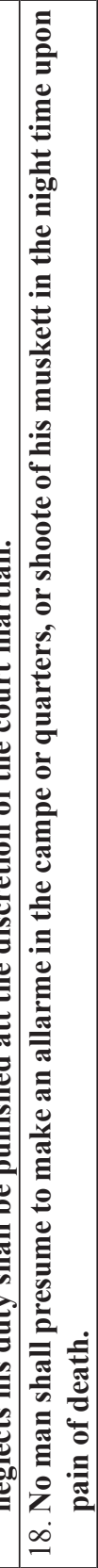 & 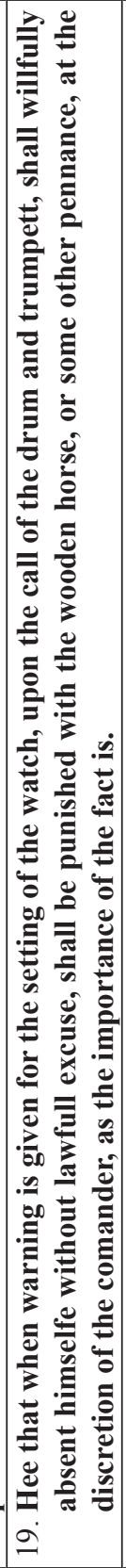 & 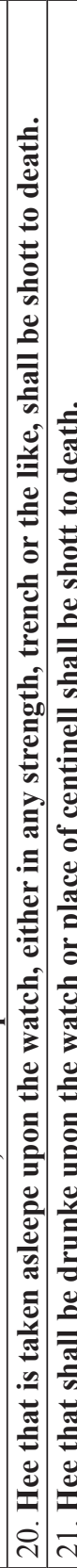 & 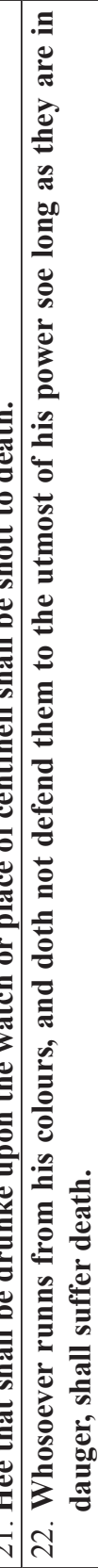 & 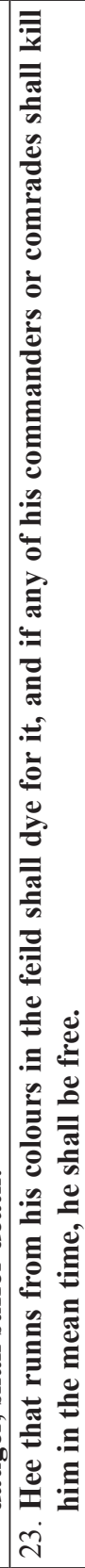 & 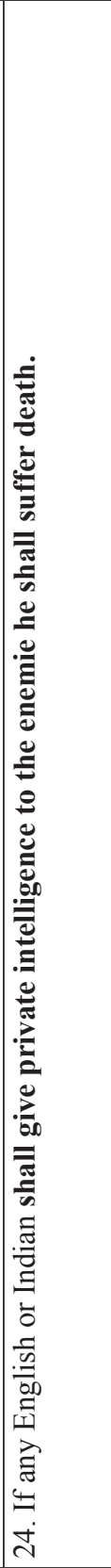 & 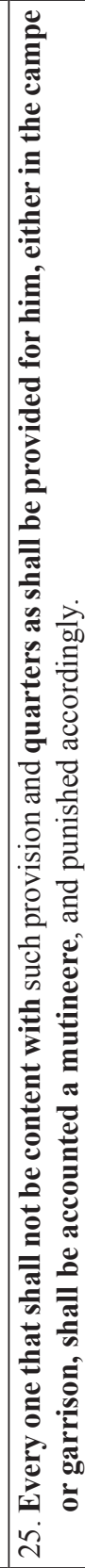 & 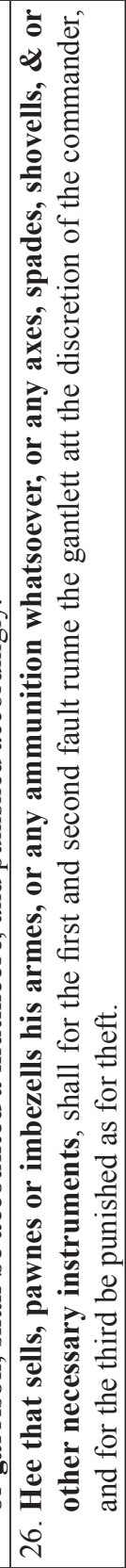 \\
\hline
\end{tabular}


had their own colony called "Nya Sverige" ("New Sweden," which encompassed parts of the present-day states of Delaware, New Jersey, Pennsylvania and Maryland) between 1638 and 1655 . This state prepared a specially edited version of the military articles while it was organizing the first expedition to America in $1637 . .^{50}$

The layout of the 1676 act needs to be positively evaluated. The number of articles and their contents were adjusted to the possibility of forming militia units. This army was not able to adopt the numerous regulations which were forced upon professional or mercenary units. ${ }^{51}$

The contents of the military articles of 1676 can be divided into 6 chapters. The articles concern religion (1-4), discipline and obedience (6-14), rules of military service $(5,15-17,24-26)$, watch (18-21) and battles (22-23).

The first article states that blasphemy against God was a crime and drunkenness was not considered to be an extenuating circumstance. The following two articles pertained to soldiers' behaviour which was deemed unworthy of Christians, namely denouncing the sacraments or other dogmas of faith, for which they ought to have been punished by an officer. Finally, article 4 ordered soldiers to take part in public prayers - twice daily - as well as to behave properly during the prayers.

This group of regulations is of special interest to historiography as it confirms the thesis according to which the colonists were strongly attached to protestant faith. ${ }^{52}$ However, comparing the aforementioned regulations with contemporary military laws in Europe proves that they were characteristic as such norms were known throughout Europe. Moreover, their hypothesis and directives constitute a faithful recreation of the solutions used in the Swedish army. ${ }^{53}$ One can find references to Swedish specificity in numerous other English military articles. ${ }^{54}$

${ }^{50}$ A. Johnson, The Swedish Settlements on the Delaware 1638-1664, vol. 1, Philadelphia 1911, p. 104. Similarly, on the basis of the Dutch "Artikelbrief," the Dutch West India Company issued provisional regulations for the first settlers in North America on the $8^{\text {th }}$ of March 1624. E.T. Pritchard, Native New Yorkers: the legacy of the Algonquin people of New York, San Francisco 2002, p. 156.

${ }^{51}$ An example of this can be the levy en masse of the crown nobles in 1621. An act was proclaimed then which consisted of just 23 legal regulations. Biblioteka PAN in Kórnik, 330, pp. 752-756; Libraries of PAN and PAU Cracow, 2253, pp. 272-273.

${ }^{52}$ For instance: J.B. Dillon, B. Douglass, Oddities of colonial legislation in America: as applied to the public lands, primitive education, religion, morals, Indians, etc., Indianapolis 1879, pp. 31-32.

${ }^{53}$ Code of articles of king Gustavus Adolphus..., articles 2-4, p. 907; The Svvedish discipline, pp. 39-69; R. Ward, Animadversions of Warre, articles 2-4, pp. 40-41; compare with K. Łopatecki, Nabożeństwa wojskowe $w$ Rzeczypospolitej szlacheckiej: zarys organizacyjno-prawny [Military religious services in the Nobles' Republic: an outline of the organizational and legal framework] [in:] T. Ciesielski, A. Filipczak-Kocur (eds.), Rzeczpospolita państwem wielu narodowości i wyznań, XVI-XVIII wiek [The Polish-Lithuanian Commonwealth as a state of numerous nationalities and creeds between the $16^{\text {th }}$ and the $18^{\text {th }}$ century], Warsaw-Opole 2008, pp. 521-539.

${ }^{54}$ Compare with Articles and Ordinances of War for the Present Expedition (1643) [in:] The Harleian Miscellany, vol. V, London 1810, articles 1-4, pp. 422-423; Articles and Rules for 
Undoubtedly, the publishing of a book entitled The Svvedish discipline, religious, civile, and military in London in 1632 played a large part. The book was divided into three parts. The first one discussed prayers and religious services in the Protestant army of Gustav II Adolf. The second part contained military articles, while the third one described rules pertaining to military order..$^{55}$

The fundamental part of the 1676 normative act was devoted to obedience and military discipline. These regulations are universal in character, the issues they deal with are prevalent in almost all modern military articles; however, their contents are identical with the Swedish norms. ${ }^{56}$ Article 6 is fundamental in character and it ordered all soldiers and officers to obediently carry out the orders of the unit's commanding officer or his second-in-command. Their orders were supposed to be obeyed as if they were issued by the king himself. This regulation describes soldiers' duties, while the sanctions for disobedience are contained within the next article. The officers were authorized to administer punishment and they had latitude in the choice of punishment depending on the severity of the infraction. The next two regulations describe the most dangerous forms of insubordination - verbally denouncing the commanding officer as well as a physical attack on him (article 8 and 9). ${ }^{57}$ Both these cases incurred the strictest punishments which were to be adjudicated by a higher military court.

A specific institution was employed in respect to the colonists which is called "Royal Voice" in the science of law and history. English commanding officers used the "royal we" form while reading some of the legal regulations included in the military articles, thus they directly equated the legal norm with the king's will. Thereby the regulations had special importance and the form of their presentation was especially celebratory. ${ }^{58}$ One can find such a case in article 6 which describes the penalization of all forms of refusing to obey an order or performing an order improperly. Disobedience could have been treated as treason or mutiny in such instances. These felonies were not directly mentioned in the discussed normative act. ${ }^{59}$

the Better Government (1673) [in:] G.B. Davis, A Treatise on the Military Law..., articles 1-6, pp. 567-568.

${ }_{55}$ The Svvedish discipline, part I (pp. 1-35), part II (pp. 39-73), part III (pp. 75-90).

${ }_{56}$ The regulations differ in single words only. Code of articles of king Gustavus Adolphus..., articles 18-22, 26, 33, 35-36, pp. 908-909.

${ }^{57}$ A characteristic of crimes of verbally denouncing the king or one of the officers: J.G. Kester, Soldiers Who Insult the President: An Uneasy Look at Article 88 of the Uniform Code of Military Justice, "Harvard Law Review" 1968, vol. 81, no. 8, pp. 1701-1706.

${ }_{58}$ M. Griffin, Regulating Religion and Morality in the King's Armies 1639-1646, LeidenBoston 2004, pp. 126-130, 157-158, 178, 184-191, 224.

${ }^{59}$ Numerous examples of employing this legal construct took place after the so-called Bacon's Rebellion was suppressed. Documentation pertaining to 10 court sessions is known. The sessions took place in January $(11-12,20,24)$, March $(1-3,8-10,15-17,22)$ and September (28) of 1677. Indictments pertained to treason and participating in a rebellion against the king ("treason and re- 
One of the most characteristic modern military crimes was disturbing camp peace by attacking another soldier, which is described in articles 10 to 13 . A consequence of striking a fellow soldier with a hand, irrespective of whether the swing was a hit or a miss, was subject to the penalty of losing one's right hand. This regulation is penalized further in articles 12 and 13 which state that wounding another soldier or drawing a sword within the confines of the camp would be punished by death. ${ }^{60}$

Article 11 has an interesting character as it considers misinforming a superior or behaving improperly towards an officer to be crimes. Article 14 afforded special protection for officers performing law enforcement services or enforcing court orders. In Europe, law enforcement officers were called "provosts" and "masters of justice" (executioners), while the word "marshall" was used here. ${ }^{61}$ People impeding them in performing their official function could be punished by death. ${ }^{62}$

Part of the act was devoted to the rules concerning keeping watch (articles 18-21). Each soldier ought to keep watch if called to do so personally or by means of sound signals. Unwarranted absence was subject to disciplinary action. The most severe punishment was given to people sleeping during their watch or those who were drunk while keeping watch or while guarding the fortifications. Moreover, the institution of quiet hours was introduced, which was commonly employed by European armies. Unjustified raising the alarm (causing anxiety) or firing a shot could have both been punished by death. ${ }^{63}$

bellion against his majestie or rebellions, treasons and misdemeanors by him committed against his majestie"). After the accused was found guilty, a verdict of death penalty was returned, most frequently by hanging. The Governor could have pardoned the condemned prisoners and could have commuted their punishment to banishment or fine. W.W. Hening (ed.), The Statutes at Large..., vol. II, pp. 545-558. Compare with K. Baran, High Treason in England until The End of Stuart Era, "Zeszyty Naukowe Uniwersytetu Jagiellońskiego. Prace Prawnicze" [Scientific Notebooks of the Jagiellonian University. Legal papers] 1982, no. 96, passim.

${ }^{60}$ These regulations have their counterparts in The Summarie of the Marshall Lawes, which were published for the forces stationed in Virginia in 1611. For The Colony in Virginea Britannia, article 9, p. 21: "Where a quarrell shall happen betweene two or more, no man shall betake him unto any other Arms then his sword, except he be a Captaine or Officer, upon paine of being put to death with such Armes as he shall so Take."

${ }^{61}$ There were specially appointed law enforcement bodies already in the first militia units in the American colonies. See: C.H. Karraker, The Seventeenth Century Sheriff: A Comparative Study of the Sheriff in England and in the Chesapeake Colonies, 1607-1689, Philadelphia 1930, p. 65 et seq; P.A. Bruce, Institutional History of Virginia..., pp. 590-604.

${ }^{62}$ More on the provost's function in the English armies: H. Marshall, Military Miscellany; Comprehending a History of the Recruiting of the Army, Military Punishments, London 1846, pp. 132-133.

${ }^{63}$ More on this institution: K. Łopatecki, Instytucja 'wytrębowania hasła'w wojskach Rzeczypospolitej Obojga Narodów [The institution of 'password spreading' in the Polish-Lithuanian Commonwealth], "Białostockie Teki Historyczne" [Bialystok's Historical Files], 2005, no. 3, pp. 75-99. 
The regulations also raised the issue of crimes committed in the course of fighting (articles 22 and 23). Two especially dangerous crimes were highlighted. The first one concerned deserting one's unit ("colours") in need, which was to be punished by death, as each soldier ought to "defend them to the utmost of his power soe long as they are in danger." It is worth emphasizing that the reception of Swedish legal norms resulted in the presence of identical regulations in the military law of Russia, the Grand Duchy of Lithuania, and in the Crown of the Kingdom of Poland. ${ }^{64}$ The second crime constituted the most characteristic military law regulation of modern times. A deserter from the battlefield who runs from his colours and comrades deserves to die. Consequently, this norm authorized both the officers and common soldiers to kill the deserter in the act with impunity. It needs to be added that the construction of this legal norm was already present in Roman law. ${ }^{65}$ On European soil, several German states, the Polish-Lithuanian Commonwealth and Russia adopted this norm and based it on the Swedish model. ${ }^{66}$ Analogous regulations were used in relation to professional soldiers in England as well as in relation to English soldiers dispatched to the Caribbean islands or to the east coast of North America. An example of this was General Robert Venables' universal issued to the British forces stationed in Jamaica in 1655. He ordered soldiers standing closest to a deserter to shoot him under pain of death. ${ }^{67}$

Article 24 was also extremely significant as it declared martial law in the colony. The hypothesis of this norm pertained not only to the soldiers but to all its inhabitants, Europeans and Indians alike. Every person who committed treason in any manner, especially if they provided information to the enemy, could have been sentenced to death. It needs to be mentioned that the General Assembly added an extra regulation as it introduced the discussed act. The regulation changed the law

${ }^{64}$ Artykuty Wtadystawa IV [Articles of Ladislaus IV], title VII, article 1, p. 214; Усmaвb Воинский, Артикуль Воинский с кратким толькованием [in:] К.А. Софроненко (ред.), Памятники русского права, Вып. 8: Законодательные акты Петра I, первая четверть ХVIII в., Mосkва 1961, article 94, p. 341. Compare with K. Koranyi, Z badań nad polskimi i szwedzkimi artykułami wojskowymi XVII stulecia [From the studies of the Polish and Swedish military articles from the $17^{\text {th }}$ century] [in:] Studia historyczne ku czci Stanistawa Kutrzeby [Historical studies in honour of Stanisław Kutrzeba], vol. I, Cracow 1938, p. 279.

${ }^{65}$ Arrius Menander in: Digesta 49. 16. 6. 3: "Qui in acie prior fugam fecit spectantibus militibus propter exemplum capite puniendus est.” See: C.E. Brand, Roman Military Law, Austin 1968, p. 184.

${ }^{66}$ Schwedisches Kriegs-Recht oder Articuls-Brieff desz [...] Herrns Gustaff Adolffs [...], Heylbrunn 1632, titulus IX, article 47, p. 16; Artykuty Władystawa IV [Articles of Ladislaus IV], Nacionalnaâ Biblioteka Rosii, Petersburg, Avt. Dubrovskogo, f. 321.2, no. 243, articles 29, 32, p. 3v; List artykutów żotnierskich [...] urodzonemu Panu Mikołajowi Abramowiczowi [A list of soldiers' articles (...) to Mr. Nicholas Abramovich], Nacionalnaâ Biblioteka Rosii, Petersburg, Avt. Dubrovskogo, f. 321.2, no. 244, article 20, p. 13.

${ }^{67}$ H. Marshall, Military Miscellany..., p. 127. 
and customs employed among the civilian population. It was decided that in face of danger all men, especially soldiers, should bear arms at all times. Men were to carry arms even during church services or during trials at courthouses. ${ }^{68}$

The last group of regulations concerned rules of service in the militia (articles $5,15-17$, and $25-26$ ). Article 5 is very interesting as it ordered that silence was to be maintained during marches and stops. It is the only original regulation found in this act. Naturally, analogous solutions were present in the contemporary military law; however, this legal construct is unique in character. The fact that it was so highly placed also needs to be given proper consideration as it was located directly after regulations concerning religion and before the norms related to obedience. One ought to conclude that this regulation was supposed to constitute a remedy for the behaviour of the contemporary militia units. It is also attested by the fact that this regulation was the only one to be issued with a justification in the act. The following is the wording of the justification: "That the commandes of the officers may be the better understood." ${ }^{69}$

Another group of regulations contains articles 15-17 which pertained to work carried out by the militia. Soldiers were ordered to submit to orders concerning any and all type of works, including constructing fortifications. A person carrying out orders in a lazy manner was subject to punishments just like officers who carelessly supervised their subordinates. It needs to be emphasized that citizens volunteering to the militia were to be given equipment. According to orders, each soldier was to be given not only provisions and weapons at the meeting point but also additional equipment necessary for waging war: axes, shovels, mattocks, etc. ${ }^{70}$ Weapons, ammunition, and tools all were under legal protection. Persons who were found to be selling, pawning, or destroying them were subject to punishment (article 26). Additionally, article 25 ordered soldiers to be obedient regarding the allocation of positions or quarters. Failure to obey these rules was considered mutiny.

In summary, the discussed act was far more general in character than the regulations issued at the time for professional armies. The legislator concentrated only on

\footnotetext{
${ }^{68}$ W.W. Hening (ed.), The Statutes at Large..., vol. II, p. 333.

${ }^{69}$ The Articles, rules and orders..., article 5, p. 334. Such line of argumentation was gladly employed in the science of law in Europe. The quoted formula was argumentum a causis in character, namely it indicated a new purpose of a legal disposition (causa finalis). Compare with H. Lausberg, Jandbook of Literary Rhetoric. A Foundation for Literary Study, transl. D.E. Orton, Brill 1998, passim (especially pp. 138-140, 165-188 et seq); W. Uruszczak, Argumenty retoryczne w Statutach Kazimierza Wielkiego [Rhetorical arguments in the Statutes of Casimir III the Great] [in:] J. Malec, W. Uruszczak (eds.), Dawne prawo i myśl prawnicza. Prace historyczno-prawne poświęcone pamięci Wojciecha Marii Bartla [Old law and legal thought. Law and history papers in memoriam of Wojciech Maria Bartel], Cracow 1995, pp. 267-282.

${ }^{70}$ An act for the safeguard and defence of the country against the Indians [in:] W.W. Hening (ed.), The Statutes at Large..., vol. II, p. 329.
} 
several most important issues, which is understandable. Most attention was paid to obedience of subordinates to their superiors. In accordance with the convention of the period, a lot of space was devoted to the issues concerning morality and religion. These regulations were not novel; however, it is significant to note that they appeared in such a short act, which only contained 26 articles. Furthermore, the act dealt with three problems which were decisive in relation to soldiers' combat ability: watch, battle and rules of service. The most important norms were articles 6 and 24 . The former introduced basic rules of obedience, while the latter formally declared martial law in the Colony of Virginia.

It needs to be emphasized that The Articles, rules and orders of 1676 did not constitute a transient episode as the General Assembly enacted resolutions pertaining to defence against the Indians' aggression once again in 1679. The resolutions were similar to the ones issued four years earlier. Such issues were decided as building additional forts, conscription of militia, designation of areas where military forces were to be stationed, procurement for the forces, compensation for lost horses, etc. The subject matter of military discipline was also not omitted as it was indicated that previously issued articles were in force. ${ }^{71}$ Other colonies (Massachusetts, Maryland, and Connecticut) based their actions on the decisions of the General Assembly in Virginia of 1675 and 1676 and they also promulgated analogous normative acts.

\section{MILITIA ARTICLES ENACTED BETWEEN 1675 AND 1676 (MASSACHUSETTS, CONNECTICUT, AND MARYLAND)}

Parallel to the situation in the Colony of Virginia, the northern colonies of Massachusetts, Connecticut, Rhode Island, and Maine had to face the Indian tribes led by Metacomet between 1675 and 1676. The militias conscripted at the time received special military articles, which was the next step in the evolution of this institution.

Militia forces were formed in Massachusetts already in the $30 \mathrm{~s}$ of the $17^{\text {th }}$ century. At the time, the colonists decided that in case of danger the forces would be assembled. It was already decided in 1631 that a weapon needed to be in every household and it should be taken on every longer journey outside of Boston. Furthermore, a chain of command was gradually taking shape. First, two quartermasters were commissioned in 1634 and then John Samford was appointed army inspector in 1636. Finally, the first general was commissioned in 1642. Commander-in-chief was obliged, first and foremost, to care for supplies, especially for ensuring a supply

${ }^{71}$ W.W. Hening (ed.), The Statutes at Large..., vol. II, pp. 433-440. 
of weapons and ammunition for soldiers. ${ }^{72}$ Legislative assemblies issued only one political instruction for the commander-in-chief of the expeditionary force during the war of 1645 . It was a general authorization to employ the rules of military discipline. ${ }^{73}$

Within the course of 30 years, the colony developed its militia and incorporated it into a legal framework. Everyone who turned 16 was conscripted into local armed forces unless they held one of the numerous offices which exempted one from military service. Thus conscripted soldiers were obliged to attend a 6-day or an 8-day military training course each year in times of peace. The richest, who had an income of more than 100 pounds, who could afford to buy a horse and the necessary equipment, could enter the cavalry. Permanent military forces were expanded in times of danger. Initially, there were only three units and their number was increased to six in 1677. Each unit was comprised of 64 soldiers, 2 musicians and officers. County commanders, called "Sergeant Major," were chosen for a period of three years. The duty of each commander was to "instruct and exercise the Officers and Souldiers in Military discipline according to his best skil and Ability." On the other hand, captains were the commanding officers in towns and forts. A characteristic and specific feature was that the officers (captains, lieutenants, ensigns) were chosen by people in the military service and that choice was subsequently approved by the most important legislative body in the colony. This solution was in force until 1668 and it drew upon old European military customs from the $16^{\text {th }}$ century. These customs consisted in self-governance of soldiers (Landsknechte) which included the possibility of choosing officers. These rules were adopted by "The Perfect Militia" in the $17^{\text {th }}$ century in England. ${ }^{74}$ The commanding officer

72 J.S. Radabaugh, The Militia of Colonial Massachusetts, "Military Affairs" 1954, no. 18, pp. 2 and 6; compare with O.A. Roberts, History of the Military Company of the Massachusetts, now called the Ancient and Honorable Artillery Company of Massachusetts, 1637-1888, vol. 1: 16371738, Boston 1895, passim.

${ }^{73}$ D. Pulsifer (ed.), Records of the Colony of New Plymouth, in New England, vol. I: 16431651, Boston 1859, p. 37; F.F. Zelner, A Rabble in Arms..., p. 28.

${ }^{74}$ Such method of soldiers' functioning was described by the term "free soldier" (German: Landsknecht) to differentiate it from the disciplined mercenary and the professional standing armies which were taking shape in the $18^{\text {th }}$ century. O. v. Nimwegen, The Transformation of Army Organization in Early-Modern Western Europe, c. 1500-1789 [in:] European Warfare, 1350-1750, Cambridge 2001, pp. 161-171. Soldiers' self-governance was very advanced until the $18^{\text {th }}$ century in the Polish-Lithuanian Commonwealth. Special parliamentary sessions were organized there by soldiers of both individual military units as well as of the whole military. J.J. Sowa, O prawnych aspektach dyscypliny w siłach zbrojnych Rzeczypospolitej [Legal aspects of discipline in the military forces of the Polish-Lithuanian Commonwealth], CPH 2014, vol. LXVI, issue 1, pp. 449-450; J. Urwanowicz, Wojskowe 'sejmiki'. Koła w wojsku Rzeczypospolitej XVI-XVIII wieku ['Military 'parliaments'. Councils in the military of the Polish-Lithuanian Commonwealth from the $16^{\text {th }}$ to the $18^{\text {th }}$ century], Bialystok 1996. 
of a unit in Massachusetts had the right to punish soldiers by employing regular (light) sanctions provided for in military law. The deciding factors were the habits and the will of the commanding officer. More serious cases which could have been punished by death were handed over to the Massachusetts General Court, which had the powers of a court martial. ${ }^{75}$

As a result of the defeats at the hands of Indians in 1675, the General Court enacted a number of regulations in October in order to improve soldiers' fighting capacity. It was stipulated that pikemen were to be substituted with musketeers. In order to make this possible, 1000 muskets were purchased in England. ${ }^{76}$ Moreover, a decision was made to reorganize the militia and to increase its numbers. However, the promulgation of the act of $26^{\text {th }}$ October 1675 entitled "Severall lawes and ordinances of war [...] for the better regulating their forces and keeping their souldiers to their duty, and to prevent profaness that iniquity be kept out of the camp" was of key importance. They were rules of military discipline, which were published in John Foster's publishing house in the same year. ${ }^{77}$ Contrary to the situation in Virginia, the General Court of Massachusetts did not approve the previously created laws but it made military articles by itself. This process was probably facilitated by a committee assembled for this very purpose. ${ }^{78}$ The regulations were composed of 20 articles and they pertained to discipline in the colonial units taking part in the fighting with the armies of King Philip..$^{79}$ The first three articles pertained to religious matters. Blasphemy against the Holy Trinity was forbidden ("the holy and blessed Trinity, God the Father, God the Son, and God the Holy Ghost"). Additionally, all soldiers were obliged to attend prayers and services (articles 1 and 3). Article 2

75 W.H. Whitmore (ed.), The Colonial Laws of Massachusetts: reprinted from the edition of 1660, Littleton 1995, pp. 56-61; W.N. Sainsbury (ed.), Calendar of State Papers, Colonial Series, America and West Indies, vol. 10: 1677-1680, London 1896, pp. 137-138; J.S. Radabaugh, The Militia..., pp. 1-18; J.M. Collins, Martial Law.., p. 216; K.F. Zelner, A Rabble in Arms..., pp. 28-34.

${ }^{76}$ K.F. Zelner, A Rabble in Arms..., pp. 40-41. It is worth mentioning that there was a general tendency on the part of European armies which were engaged in warfare in the New World to stop employing pikemen in favour of musketeers quite quickly. For instance, the army of the Dutch West India Company in 1636 had a complement of 1200 men which included only 50 pikemen. K. Łopatecki, Ofensywa Holenderskiej Kompanii Zachodnioindyjskiej w Brazylii w latach 16341636 [The Dutch West India Company offensive in Brazil from 1634 to 1636], "Prace Historyczne" [Historical papers] 2016, vol. 143, no. 4, p. 696.

77 Severall lawes and ordinances of war, Boston 1675; N. Paine, A list of early American imprints, 1640-1700, Worcester 1896, p. 28. The contents of the articles were reprinted in: W.N. Sainsbury (ed.), Calendar of State Papers..., vol. 9, pp. 299-300; F. Baylies, An Historical memoir of the Colony of New Plymouth, ed. S.G. Drake, vol. II, Boston 1866, pp. 89-91; N.B. Shurtleff (ed.), Records of the Governor and Company of the Massachusetts Bay in New England, vol. V: 1674-1686, Boston 1854, pp. 49-50; C. Rex, Anglo-American Women Writers and Representations of Indianness, 1629-1824, London-New York 2016, p. 31.

${ }^{78}$ First such committee was created in 1663. J.S. Radabaugh, The Militia..., p. 8.

79 K.F. Zelner, A Rabble in Arms..., pp. 41-69. 
forbade making false oaths, uttering words as well as committing acts against God and morality. ${ }^{80}$ It also needs to be added that Indians who fielded allied units had to abide by fundamental moral and religious norms. The act passed on the $13^{\text {th }}$ of May 1675 in Hartford testified to this fact as it granted rights to the Pequot tribe but it also imposed certain responsibilities on them. ${ }^{81}$

The legal regulations put the biggest emphasis on the issues connected with obedience and with the chain of command. This was especially significant as there were strong democratic tendencies in the militia units (electing commanding officers until 1668, participation in the judiciary). In contrast with the military legislation which was in force in Virginia, the crime of soldiers' mutiny was included in the legislation in Massachusetts. Mutineers, as well as people persuading others to collective disobedience, should be punished by death. Informing on such people was also prescribed on pain of severe punishment (articles 10 and 11). Articles 5 and 8 were the other regulations prescribing obedience. They forbade quarrelling with superiors, while an attack on an officer was punished by death. Article 4 introduced a general rule according to which each soldier or officer who carelessly carried out their duties ought to have been punished as their superior saw fit.

Article 7 contained an interesting regulation. It prescribed that soldiers ought to observe silence both during marches and while in stationary positions. A justification was added here which was a rare occurrence in the colonial military articles. According to the legislator, it was an indispensible prerequisite in order to enable commanding officers to issue orders which were to be heard and obeyed. This regulation was directly connected with article 5 concerning militia rights published in Virginia in 1676. Other, almost identical, regulations present in both colonies

${ }^{80}$ K. Maćkowska, Przestępstwa $i$ kary $w$ regulacjach prawnych $w$ nowoangielskich kolonii w Ameryce Pótnocnej w XVII wieku [Crimes and punishments in legal regulations in the new English colonies in North America in the $17^{\text {th }}$ century], "Zeszyty Prawnicze" [Legal Paper] 2011, vol. 11, no. 2, pp. 285-286, 289-290.

${ }^{81}$ Laws for the Said Indians to observe, [in:] R.R. Hinman (ed.), Letter from the English King and Queens Charles II, James II, William and Mary, Anne, George II, to the Governors of the Colony of Connecticut, together with the answers thereto, from 1635 to 1749, Hartford 1836, pp. 93-95. The points concerning religious issues were chosen from this 10-point act: " 1 . That whosoever shall oppose or speake against the onely liveing and true God, the creator and ruler of all things, shall be brought to some English Court to be punished as the nature of the offence may require. 2. That whosoever shall powaw or use witchcraft or any worship to the Devill, or any falls God, shall be so convicted and punished. 3. That whosoever shall profane the holy Sabbath day by servill work or play, such as chopping or fetching home of wood, fishing, fowling, hunting \&:c., shall pay as a fine tenn shillings, halfe to the cheife officers, and the other halfe to the constable and informer, or be sharply whipt for every such offence. 8 . It is ordered that a ready and comely attendance be given to heare the word of God preached by Mr. Fitch, or any other minister sent amongst them. The cheife officers and constables are to gather the people as they may, and if they be refractory and refuse, or doe misbehave themselves undecently, such shall be punished with a fine of five shillings, or be corporally punished as the officers shall see most meet." 
were articles 9 through 14. They included special legal protection of the provosts and of persons responsible for maintaining order in the army.

The legislator devoted a lot of space to the problem of common crimes committed by soldiers against the civilian population. And so capital punishment was provided under the provisions of law for all rapists and persons guilty of "unnatural abuses." Sexual infidelity and prostitution were also punished (articles 13-16). On the other hand, theft and robbery were treated much more leniently than in Europe. Death penalty (at least de jure) was dominant on the Old Continent, while fines were the form of punishment employed in America. The most serious felony included in this group of regulations was murder which was, naturally, punished by death. In conclusion, the legislative body introduced stricter punishments for common crimes committed by soldiers. ${ }^{82}$

The discussed act also contains examples of military crimes which indicate the presence of pathologies among the colonial units. Among the most serious was desertion, which was understood as deserting one's unit or commanding officer, and, obviously, it was punished by death (article 6) ${ }^{83}$ Furthermore, drunkenness was a common vice. However, it was not always fought against with legal acts. In this case, the legislator unequivocally decided that a person abusing alcohol should not be an officer and should be demoted. However, a common soldier was to be punished according to the court's discretion for this type of behaviour (article 12). ${ }^{84}$

However, the most basic problem was the issue of soldiers' equipment. Natural$1 \mathrm{y}$, recruits received weapons and tools but they encashed them willingly whenever they needed ready money. And so soldiers were ordered to be in full pack while on duty. Losing one's weapon, regardless of the circumstances, was considered a crime, especially if it was lost while playing dice or cards. Additionally, destroying or selling ammunition was forbidden (articles 17-19). ${ }^{85}$

Similarly to Virginia, the military articles created in Massachusetts were based on one model legal act. A detailed comparative analysis leads to the conclusion that laws for the militia were published on the basis of military regulations proclaimed

${ }^{82}$ In certain cases, the law in force in civilian frameworks was rigorous enough that it was not necessary to introduce separate regulations into military articles. See: the crime of paedophilia enacted in Boston (1654): "If any man shall unlawfully have carnall copulation w[th] any woman child under ten years ould, hee shall bee put to death, whether it were w[th] or w[th]out the girls consent." N.B. Shurtleff (ed.), Records of the Governor..., vol. II, p. 21.

${ }^{83}$ Additional reading on desertion in the English armies stationed in North America in the middle of the $18^{\text {th }}$ century: S.N. Hendrix, The Spirit of the Corps: The British Army and the Pre-National Pan-European Military World and the Origins of American Martial Culture, 1754-1783, Pittsburgh 2005, pp. 123-128.

${ }^{84}$ Drumming out of the army for drunkenness was a characteristic solution in English legislation. Lavves and Ordinances militarie, Leiden 1586, article 7, p. 5.

${ }^{85}$ K.F. Zelner, A Rabble in Arms..., p. 43. Since the middle of the $17^{\text {th }}$ century, each infraction in armaments was punished with a fine of 10 shillings. The Colonial Laws of Massachusetts, p. 57. 
(and published in print) by Robert Devereux, the $3^{\text {rd }}$ Earl of Essex, in $1642 .{ }^{86}$ The majority of regulations is almost identical and there are alterations only in few cases (articles 11, 15, 17). What is more, even the layout of the regulations is identical. Only the last norm of this normative act is original in character and it concerns the employed types of military punishments (Table 2 ).${ }^{87}$ The fragments corresponding in both versions are underlined. ${ }^{88}$

In Connecticut, a War Council, specially assembled by the governor, was in session since the $1^{\text {st }}$ of July 1675 . Robert Treat was appointed the commander-in-chief of the colonial forces on the $30^{\text {th }}$ of August. When the nomination was announced, he was ordered to maintain military discipline in the army and punish criminals according to military law. ${ }^{89}$ It needs to be presumed that customary law was employed on the basis of regulations issued in the metropolis for the English forces. Finally, during the session of this body on the $10^{\text {th }}$ of January of 1676 in Hartford, a regulation was passed "for the better regulateing their for ces and keeping their souldiers to their duty, and to prezent profanesse." ${ }^{.90}$ It is also a 20-point regulation which corresponds to a great extent with the laws published for Massachusetts.

All the regulations are counterparts of the Massachusetts regulations. The order was only disturbed in case of articles 9 and 10 which were placed the other way around. Legal writing units are frequently identical as is the case with articles 2, 3, $4,7,12,14-18$, and 20 . The others differ only in single words or phrases which do not change the meaning of the legal norm in any way. This takes place, inter alia, in articles 1 and 11 (where the phrase "grevious punishment" was substituted with "severe punishment") as well as in 13 (where "unnatural abuses" was substituted

${ }^{86}$ D. Godfrey, The Parliamentary Army under the Earl of Essex, 1642-5, "English Historical Review" 1934, no. 49, pp. 32-54; C.H. Firth, Cromwell's army: a history of the English soldier during the Civil Wars, the Commonwealth and the Protectorate, London 1902, pp. 279-282, 400412.

${ }^{87}$ H.E. Selesky, War and Society in Colonial Connecticut, New Haven 1990, p. 26, indicated that the normative act constituted the reception of the legal solutions found in the New Model Army in England.

${ }^{88}$ The regulations found in Lawes and Ordinances of Warre Established for the better Conduct of the Army by His Excellency the Earle of Essex, London 1642, do not have continuous numbering; they are divided into chapters which were entitled: "Of Duties to God" (I), "Of Duties in generall" (II), "Of Duties toward Superiours and Commanders" (III), "Of Duties Morall” (IV), "Of a Souldiers Duty touching his Armes" (V), "Of Duty in marching" (VI), "Of Duties in the Campe, and Garrison" (VII), "Of Duties in Action" (VIII), "Of the duties of Commanders and Officers in particular" (IX), "Of the dutie of the Muster Masters" (X), "Of Victuallers" (XI), "Of Administration of Justice" (XII).

${ }^{89}$ At a meeting of the Councill, August 28, 1675 [in:] J.H. Trumbull (ed.), The Public Records of the Colony of Connecticut from 1665 to 1678; with the Journal of the Council of War 1675 to 1678, Hartford 1852, p. 357.

90 J.H. Trumbull (ed.), The Public Records..., pp. 392-394. The publisher committed an obvious error by indicating that laws of war were enacted on the $10^{\text {th }}$ of January 1675 . 


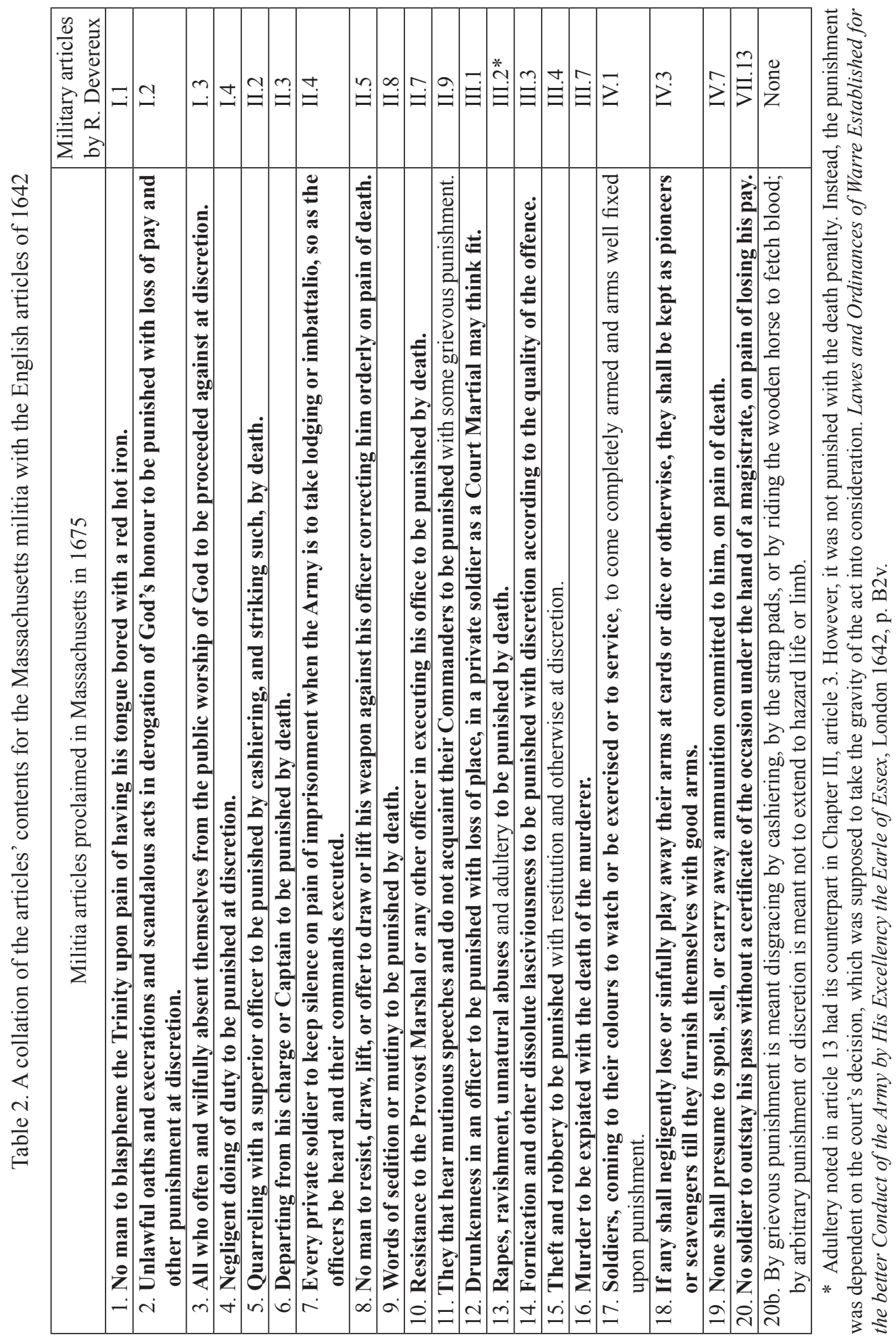


with "sodomy"). The most far-reaching modifications consisted in introducing different sanctions while maintaining the hypothesis and disposition, among others, in articles 5, 6, 8-10, and 19. The more severe regulations were placed in the articles for soldiers from Massachusetts. The laws created in Connecticut frequently gave the option of a more lenient punishment in case of crimes which had a fixed death penalty.

Borrowing solutions from Massachusetts was connected with the expedition against the Narragansett tribe in December of 1675. It was a part of the skirmishes during King Philip's War. It was the time when the armies from Connecticut, Massachusetts, and Plymouth set forth on an expedition against a tribe of Metacomet's alleged allies. The articles which had been previously promulgated in Massachusetts were in force during this offensive. ${ }^{91}$

It should be presumed that the issued laws had a good effect on the discipline level in the units. As Edward Randolph wrote in October of 1676: "The militia consist of four troops of horse, and five regiments of foot, who are well armed and disciplined, no old soldiers among them. [...] They are generally very loyal and good people, and do upon all occasions express great love to the person and government of his majesty, and do heartily wish that his majesty's authority were established over the whole country." ${ }^{\prime 92}$

Shortly after, as it was 1692, the General Court of Massachusetts issued more military articles which had been prepared for the expedition to Canada. They consisted of 23 articles but they were much longer than the previous ones due to the extension of particular legal writing units ${ }^{93}$. Their characteristic exceeds the original text's framework. However, it needs to be mentioned that these regulations are largely similar to the previous solutions but they were supplemented with military discipline rules aboard ships. There also appeared institutions which were expressis verbis previously unknown such as the method of disseminating military laws (articles 1 and 2). After they were enacted by the General Court, it was necessary to proclaim without delay that they were in force in each unit as well as on every ship taking part in the military expedition. Additionally, a reading of military articles was introduced which took place cyclically, once every two weeks, and it was preceded by the sounds of drums and trumpets. As a result, no soldier could claim ignorance of the law. Such method of disseminating knowledge of military law was identical all over Europe. In the first place, the enacted regulations for the army needed to be promulgated. Subsequently, commanding officers of each unit were obliged to cyclically read the articles to their subordinates. However, the

\footnotetext{
${ }^{91}$ S.G. Drake, King Philip’s War..., pp. 89-91.

92 Ibidem, p. 167.

${ }^{93}$ Major Walley's Journal in the Expedition against Canada in 1692, "Year-Book of the Society of Colonial Wars in the Commonwealth of Massachusetts for 1898" 1898, no. 4, pp. 117-119.
} 
frequency varied as in reality this activity was carried out weekly, monthly, once in two months or quarterly. ${ }^{94}$ The period of two weeks which was stated for the armies of the Massachusetts colony seems possible to realize as the contents of the act were not overly long.

Clear rules pertaining to the method of dividing spoils of war were also introduced at the time. All the loot was supposed to be gathered together and divided equally among all the soldiers. Spoils of war were not to be touched without a commanding officer's express permission under pain of death (articles 19 and 22).

Under the influence of the solutions enacted in Jamestown and Massachusetts, the Council of Maryland and the governor also proclaimed military articles for the militia on the $13^{\text {th }}$ of June $1676 .{ }^{95}$ These laws were approved not only by Governor Charles Calvert, the $3^{\text {rd }}$ Baron Baltimore, but also by Chancellor Philip Calvert as well as by Samuel Chew, Jesse Warton, and Thomas Taillor. "The Articles of War in England and Maryland," which were created then, consisted of 53 legal regulations which were based to a large extent on "The Prince Rupert Articles" of 1672. ${ }^{96}$ The level of reception is presented in Table 3 which shows that the form and wording of a total of 47 regulations (81\%) remained unchanged. Only two articles can be considered regulations which were not taken into account in the model normative act.

Among the novel regulations, article 20 deserves attention as it introduced wide protection for the civilian population and their property. Besides the prohibition of plundering as well as of burning houses and plantations, all places of worship were placed under protection ("whether called by the name of Church Chappell or otherwise neither"), while rape was punished by death. Wide protection was also afforded to envoys sent to conduct negotiations with command (article 44). On the other hand, article 30 guaranteed that all wounded or ill soldiers would be sent to a lazaretto or to a place where they could recuperate. The families of the deceased soldiers were guaranteed livelihood (this especially pertained to children in their infancy). New legal regulations concerned logistics and, above all, ammunition and food reserves (article 35).

The information in Table 3 introduced in the comments concerned differences occurring between the texts. However, small editing and substantive changes which

${ }^{94}$ K. Lopatecki, Disciplina militaris' 'w wojskach..., pp. 35, 106, 153, 422, 492, 700; S.R. Frey, The British Soldier in America..., pp. 85-86.

${ }^{95}$ R. Semmes, Crime and Punishment in Early Maryland, Baltimore 1996, p. 297; D.W. Jordan, Foundations of Representative Government in Maryland, 1632-1715, Cambridge - New York - Melbourne - Madrid - Cape Town 1987, p. 117.

96 Archives of Maryland, Proceedings of the Council of Maryland, 1671-1681, vol. 15, Baltimore 1896, pp. 80-90; a critical edition: Articles of war in England and Maryland [in:] A.R. Semmes, Crime and Punishment..., pp. 706-707. 
adjusted a regulation to the circumstances, ranks, etc., present in Maryland were not marked. ${ }^{97}$

\section{CONCLUSIONS}

Militia articles were a specific group of military normative acts. They were addressed to civilians who only temporarily took part in warfare. However, in order to impose them on the inhabitants, it was necessary to have their contents enacted and accepted by local parliaments. ${ }^{98}$ Such legislative process had fundamental importance for the legitimization of the proclaimed military laws. For this reason, their significance and certainty regarding the necessity concerning their use was also growing. ${ }^{99}$ The contents of military laws addressed to the militia - contrary to the general tendency of constant extension of military normative acts - were abridged and they only pertained to crucial regulations. It was not even attempted to impose on such units analogous military discipline rigours, hierarchical subordination, or absolute obedience to the issued orders as was the case with professional armies. For these reasons, militia units were treated as ones characterized by lower military capability and small discipline, especially in the $2^{\text {nd }}$ half of the $17^{\text {th }}$ century and in the $18^{\text {th }}$ century. ${ }^{100}$ Despite this, the regulations created in the $17^{\text {th }}$ century constituted the first step in the development of a citizen army, which showed its strength during the American War of Independence. ${ }^{101}$

${ }^{97}$ Archives of Maryland, pp. 80-90; Articles and Rules for the Better Government of his Majesties Forces by Land During this Present War [in:] G.B. Davis, A Treatise on the Military Law..., pp. 567-580.

${ }^{98}$ It also happened in Europe that local assemblies promulgated their own military articles. For instance, in the Polish-Lithuanian Commonwealth, such actions were undertaken by local parliaments or by nobles' conventions. K. Łopatecki, Koronne artykuły wojskowe w okresie interregnum po śmierci Zygmunta Augusta [Military articles of the Crown in the interregnum period after the death of Sigismund II Augustus], "Studia z Dziejów Państwa i Prawa Polskiego" [Studies of the History of the Polish State and Law] 2012, no. 15, pp. 11-29.

${ }_{99}$ It is worth mentioning that the Governor of Carolina published military articles in 1690 without the consent of the General Assembly. This led to objections from the citizens regarding the article's legality. J.W. Fortescue (ed.), Calendar of State Papers, Colonial Series, America and West Indies, vol. 13: 1689-1692, London 1901, p. 331.

100 F.W. Anderson, Why Did Colonial New Englanders Make Bad Soldiers? Contractual Principles and Military Conduct during the Seven Year's War, "The William and Mary Quarterly" 1981, vol. 38, no. 3, pp. 395-417.

${ }^{101}$ An extremely popular and frequently repeated quote of George Washington is: "Discipline is the soul of an army. It makes small numbers formidable; procures success to the weak, and esteem to all." General Instructions to all Captains of Companies, 29.07 .1757 [in:] J.C. Fitzpatrick (ed.), The writings of George Washington from the original manuscript sources, 1745-1799, vol. 2: 15751769, Washington 1931, p. 114. 
Table 3. A collation of the contents of "The Articles of Warr" which was in force in Maryland (1676) and of "The Prince Rupert Articles" (1672)

\begin{tabular}{|c|c|c|}
\hline $\begin{array}{c}\text { Articles of } \\
\text { Warr (1676) }\end{array}$ & $\begin{array}{l}\text { Prince Rupert } \\
\text { Articles (1672) }\end{array}$ & Comments \\
\hline $1-4$ & $3-6$ & \\
\hline Pledge & Pledge & Slight differences adjusted to the circumstances \\
\hline 5 & $7-9$ & $\begin{array}{l}\text { A modified regulation which made use of the } \\
\text { solutions employed in articles } 7 \text { to } 9\end{array}$ \\
\hline $6-19$ & $10-23$ & \\
\hline 20 & 24 & Modified \\
\hline $21-22,23-24$ & $30-31,33-34$ & \\
\hline 24,25 & 35 part 1,35 part 2 & \\
\hline 27 & 36 & \\
\hline 28 & 41 and 42 & Modified \\
\hline 29 & 43 & Modified \\
\hline 30 & 46 & Modified \\
\hline $31,32,33,34$ & $47,50,52,54$ & \\
\hline 35 & $(56)$ & $\begin{array}{l}\text { A new regulation which takes into consideration } \\
\text { the assumptions included in article } 56\end{array}$ \\
\hline $36-37,38-43$ & $57-58,60-65$ & \\
\hline 44 & - & A new regulation \\
\hline $45-53$ & 66-74 & \\
\hline
\end{tabular}

The militia articles should not be viewed only from the point of view of military discipline. First and foremost, they played a crucial part in the shaping of proper attitudes among the citizens, which should be equated with the phenomenon of social discipline. Militia members transposed the habits and rules they had acquired into civilian structures upon their return home from the service. As a consequence, a process began of the influence of solutions employed in the militia in the $2^{\text {nd }}$ half of the $17^{\text {th }}$ century. In terms of system of government, it resulted in the creation of the Second Amendment of the United States Constitution. ${ }^{102}$

It is difficult to unequivocally determine the time of creation of the first laws which can be defined as militia articles and which were independently issued by the colonists. In the first decades of the colonization, the proclaimed military laws were addressed to the professional soldiers who had been sent from the metropolis. The slow process of creation and extension of colonial militia started in the $30 \mathrm{~s}$ of the $17^{\text {th }}$ century. There are single pieces of information which indicate that special

102 "A well regulated militia being necessary to the security of a free state, the right of the people to keep and bear arms shall not be infringed." See: S.P. Halbrook, That Every Man Be Armed: The Evolution of a Constitutional Right, Albuquerque 1984 (the author called on, among others, the articles proclaimed in Virginia in 1676 - p. 214). 
laws could have already been created in the $60 \mathrm{~s}$ of the $17^{\text {th }}$ century. However, the dynamic process of announcing laws for the militia of similar character to the ones binding mercenary armies was started by King Philip's War and Bacon's Rebellion. Regulations from the colonies of Virginia, Massachusetts, Connecticut, and Maryland come from 1675 and 1676.

The militia articles from Virginia, Connecticut, Maryland, and Massachusetts confirm the existing observations pertaining to the method of enacting military regulations in the modern era. They were not created "from scratch" but they were rather rewritten versions of model military laws. They were most frequently based on one normative act. ${ }^{103}$ In the researched cases, the colonists from Virginia used the articles by Gustav II Adolf of 1621; the articles for the New Model Army proclaimed by Robert Devereux in 1642 were employed in Massachusetts; and the so-called "Prince Rupert's Articles" of 1672 were drawn on in Maryland. The solution worked out in Connecticut indicates that after a version of the regulations for the militia was created in one state that they were willingly copied by neighbouring colonies. The aforementioned examples constitute a direct evidence for the free flow of military and legal knowledge which existed thanks to the dissemination of printed versions of the military articles and of their translations into foreign languages.

The influence of the Swedish military articles by Gustav II Adolf (1621) on the development of military law around the world is worth emphasizing. They were commonly accepted in the northern countries of the Holy Roman Empire of the German Nation since 1630. ${ }^{104}$ The articles were translated into German specially for the needs of the mercenary armies and allied units of Protestant duchies in 1632. At the same time, some editorial changes were made in the translation process which consisted in extending the legal regulations and making the sanctions harsher. ${ }^{105}$ Ladislaus IV Vasa, the king of Poland, adopted the Swedish norms

${ }^{103}$ Even the majority of the excellently prepared Russian military articles by Peter the Great of 1715 are based on the Swedish military laws of Charles XI of 1683 (which are similar to the articles by Gustav II Adolf of 1621). The Russians introduced only three new chapters (out of 24). E. Anners, Den Karolinska Militärstraffrätten och Peter den Stores Krigsartiklar, Uppsalla 1961, pp. 1619. These similarities stem from the fact that one of the main authors of the normative act was ober-auditor Ernst Friedrich Krompein, a Swedish officer at the Vyborg garrison. He was captured as a prisoner in 1710. М.П. Розенгейм, Очерк истории военно-судных учреждений в России до кончины Петра Великого, СПб. 1878, р. 104; П.О. Бобровский, Военные законы Петра Великого в рукописях и первопечатных изданиях, СПб. 1887, pp. 10, 30, 38, 48-50, 52-53.

${ }^{104}$ K. Ögren, Humanitarian Law in the Articles of War decreed in 1621 by King Gustavus Adolphus of Sweden, "International Review of the Red Cross" 1996, no. 313, pp. 439-440; K. Koranyi, Z badań nad polskimi i szwedzkimi..., pp. 276-277; Sveriges krig 1611-1632, n.d. vol. V: Från Breitenfeld till Lech, Stockholm 1937, pp. 300-307; M. Roberts, Gustavus Adolphus. A History, vol. II, London 1958, pp. 240-244.

${ }^{105}$ For example: Schwedisches Kriegsz-Recht, Oder Artickulß-Brieff, Des... Herrns Gvstaff Adolffs..., Halberstadt-Kolwald 1632; Schwedisches Kriegs-Recht, oder Artikuls-Brieff deß... Herrn 
with minor changes as binding law for foreign contingents and published them in Polish in $1633 .{ }^{106} \mathrm{~A}$ detailed research into military articles which were employed in the Grand Duchy of Lithuania confirmed that the Swedish body of work was also in use in this country, among others, in the laws promulgated in 1633, 1635, and 1673. ${ }^{107}$ Both sides fighting in the English Civil War also employed these regulations. It was possible because they had been translated into English twice and they had been printed in 1632 and in 1639. They became a model for future English military laws. ${ }^{108}$ Switzerland should also be counted among countries which reformed the military articles in an analogous manner. ${ }^{109}$ BrandenburgPrussia promulgated military articles in 1656 and they also drew on the Swedish solutions ${ }^{110}$. Russia only started employing modern military laws at the turn of the $18^{\text {th }}$ century and it adopted the Scandinavian solutions already in $1715 .{ }^{111}$ Among the most exotic areas of Swedish influence, one ought to count the articles for the militia in the colony of Virginia of 1676. This was not a direct reception but rather an adoption of the regulations which had been translated and published earlier in

Gustaff Adolffs, Mayntz 1632; Schwedisches Kriegs-Recht, oder Articuls-Brieff, deß... Herrns Gustaff Adolffs, Meyntz-Meres 1632; Schwedisches Kriegs-Recht oder Articuls-Brieff desz... Herrns Gustaff Adolffs..., Heylbrunn 1632; Schwedisches Kriegs-Recht, oder Articuls-Brieff deß... Herrn Gustaff Adolffs, Nürnberg-Endter 1632.

${ }^{106}$ Króla Władysława IV artykuly wojsku cudzoziemskiemu opisane [King Ladislaus IV's articles described for foreign armies] [in:] Polskie ustawy [Polish acts], pp. 209-225; compare with K. Koranyi, Z badań nad polskimi i szwedzkimi..., p. 272 et seq. The German military articles of 1632 were a model version. They contained 113 regulations. Schwedisches Kriegs-Recht oder ArticulsBrieff desz..., pp. 3-35. Just four new regulations were introduced and 22 Swedish regulations, which mainly pertained to confessional issues, were omitted. K. Lopatecki, 'Disciplina militaris' wwojskach..., pp. 524-542.

${ }^{107}$ K. Łopatecki, 'Disciplina militaris' w wojskach..., pp. 426-427, 433-437, 454-456.

108 The Svvedish discipline, pp. 39-69; R. Ward, Animadversions of Warre, pp. 41-54.

109 K. Koranyi, Über schweizerische Kriegsartikel besonders im 17. Jahrhundert, "Allgemeine Schweizerische Militärzeitschrift" 1939, no. 85, pp. 822-823.

${ }^{110}$ Churfürstliches Brandenburgisches Kriegs-Recht oder Articuls-Brieff [in:] Corpus Constitutionum Marchicarum, Oder Königl. Preußis. und Churfürstl. Brandenburgische in der Churund Marck Brandenburg, auch incorporirten Landen publicirte und ergangene Ordnungen, Edicta, Mandata, Rescripta, n.d. III, Berlin-Halle [1737], pp. 59-79.

111 The collation below shows the range of reception of Swedish law. Russian regulation is noted first and the Swedish one is next: $1,3,6,7-1,2,3,4,5 ; 8-6 ; 9-7 ; 10-9,10 ; 11-12 ; 12-13$; $15-8,11 ; 16-15 ; 17-16 ; 18-23 ; 21-24,25 ; 22-26 ; 23-29 ; 24-27 ; 25-30,28 ; 26-34 ; 27-31 ; 35-37$; $36,37-39,40,41,42,43,44 ; 38-55 ; 41-56,57$; 45-45; 46-47, 46; 48-48; 50-50; 52-51; 53, 54-53; $57-113$; 58-114; 59-115; 60-124; 62-128; 63-129; 64-135; 65-138; 66-136; 67-137; 68-139, 140 ; 69, 70-131; 71-132; 72-133, 134; 76-58; 77-59; 78-60; 80-61; 84-109; 85-110; 91-111; 92-112; 94-62; 95-63; 97-64, 66; 98-68; 101-69; 102-70; 104-116; 106-118; 107-117; 112-119; $113-123 ; 114-120 ; 116-122 ; 117-71,72 ; 118-73 ; 119-74 ; 123-75 ; 124,125-77$; 133-79; $135-$ 83 ; 138-84; 154-85; 160, 161-86; 165-98; 167-88; 169-94; 170-91; 171-97; 173, 174-95, 96; 175-89; 178-99; 181-100; 182-101; 183-107; 186-103, 104; 191-108; 192-105; 195-106; 206, 209-141, 142. See: E. Anners, Den Karolinska..., pp. 117-146. 
England. ${ }^{112}$ This impressive influence of the legal output of Gustav II Adolf would not be complete without taking its translations and printed versions in Finnish in 1642 and in Latvian in 1696 into consideration. ${ }^{113}$ Thanks to these translations, the peasants conscripted into the Swedish army could get acquainted with the regulations in a language they understood.

The significance of the printed military articles for the flow of military knowledge in the period of military revolution needs to be accentuated. ${ }^{114}$ England was a leading country in every respect in this area of knowledge and their publishing in print was almost a sine qua non condition of the military law to be employed in the units as far back as the end of the $16^{\text {th }}$ century. ${ }^{115}$ The English model was also adopted by the colonies in North America. First detailed information pertaining to the number of printed copies comes from 1746 when an expedition force to Canada was being prepared in Massachusetts. At the time, the military articles were printed twice. First, 200 copies were printed on the $6^{\text {th }}$ of June. And, just before the start of the expedition, additional 125 copies were printed on the $8^{\text {th }}$ July. ${ }^{116}$ Besides print, the knowledge of the military law regulations was disseminated among the British forces stationed in the American colonies by cyclical readings of the laws by officers. ${ }^{117}$ However, the first regulations concerning this issue are found in the militia articles of 1690 from Massachusetts.

112 W.R. Hagan (Overlooked Textbooks Jettison Some Durable Military Law Legends, "Military Law Review" 1986, no. 113, pp. 163-202) tried to diminish the influence of Gustav II Adolph's laws on the English (British) solutions and, consequently, on the American ones. The example of direct reception of the Swedish articles shown here revises W.R. Hagan's conclusions.

113 Krigs articlar såsom the aff höghlåfligh vthi åminnelse konungh Gustavo Adolpho, Stockholm 1642; Sawadi Karra-Teesas Likkumi, Riga 1696; compare with T. Jakso, Suomi. Kirjoituksia isän-maallisista aineista, 3 Osa, Helsingissä 1865, pp. 202, 211-220.

114 More on the printed works used by soldiers: D.R. Lawrence, The complete soldier: military books and military culture in early Stuart England, 1603-1645, Brill 2009, passim.

115 For instance: Statutes and ordynances for the warre, London 1544; Lawes and Ordinances militarie, Leyden 1586 (this print was reprinted once again in the same year in London by Christopher Barker). M.J.D. Cockle, A Bibliography of English Military Books, up to 1642 and of Contemporary Foreign Works, ed. H.D. Cockle, London 1900, pp. 28-29; Laws and Orders of War, established for the good conduct of the service in Ireland, Dublin 1599; B.C. Donovan, D. Edwards, British sources for Irish history, 1485-1641: a guide to manuscripts in local, regional and specialised repositories in England, Scotland and Wales, Dublin 1997, p. 163.

${ }_{116}$ Massachusetts in the Intended Expedition to Canada in 1746, ed. W.K. Watkins, "YearBook of the Society of Colonial Wars in the Commonwealth of Massachusetts for 1900" 1901, no. 6, p. 66 .

117 D.E. Leach, Roots of Conflict British Armed Forces and Colonial Americans, 1677-1763, Chapel Hill 1986, p. 127. 